\title{
ABTS On-Line Antioxidant, $\alpha$-Amylase, $\alpha$-Glucosidase, Pancreatic Lipase, Acetyl- and Butyrylcholinesterase Inhibition Activity of Chaenomeles Fruits Determined by Polyphenols and other Chemical Compounds
}

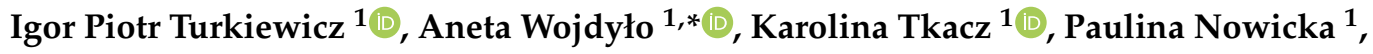 \\ Tomasz Golis ${ }^{2}$ and Przemysław Bąbelewski ${ }^{3}$ \\ 1 Department of Fruit, Vegetable and Plant Nutraceutical Technology, Wrocław University of Environmental \\ and Life Sciences, 37 Chełmońskiego Str., 51-630 Wrocław, Poland; igor.turkiewicz@upwr.edu.pl (I.P.T.); \\ karolina.tkacz@upwr.edu.pl (K.T.); paulina.nowicka@upwr.edu.pl (P.N.) \\ 2 Research Institute of Horticulture, Department of Pomology, Gene Resources and Nurseries, 1/3 Konstytucji \\ 3 Maja Str., 96-100 Skierniewice, Poland; tomasz.golis@inhort.pl \\ 3 Department of Horticulture, Wrocław University of Environmental and Life Sciences, 24a Grunwaldzki Str., \\ 53-363 Wrocław, Poland; przemyslaw.babelewski@upwr.edu.pl \\ * Correspondence: aneta.wojdylo@upwr.edu.pl; Tel.: +48-71320-7706
}

Received: 7 December 2019; Accepted: 4 January 2020; Published: 9 January 2020

check for updates

\begin{abstract}
This study aimed to identify and quantify the chemical composition and polyphenolic profile of 19 cultivars of Chaenomeles $\times$ superba, Chaenomeles japonica, and Chaenomeles speciosa by liquid chromatography coupled with photodiode array detector and quadrupole time-of-flight electrospray ionization mass spectrometry (LC-PDA-QTOF-ESI-MS). Antioxidant (ABTS on-line, ABTS, FRAP, and ORAC), as well as in vitro biological activities, i.e., the ability to inhibit $\alpha$-amylase, $\alpha$-glucosidase, pancreatic lipase, acetylcholinesterase (AChE), butyrylcholinesterase (BuChE), and 15-lipoxygenase (15-LOX) were determined. Most of the Chaenomeles species and cultivars analyzed in this study have not been examined in this respect until now. Fruits contained 30.26 to $195.05 \mathrm{mg}$ of vitamin C, 0.65 to $1.69 \mathrm{~g}$ of pectin, 0.32 to $0.64 \mathrm{~g}$ of ash, 0.60 to $3.98 \mathrm{~g}$ of sugars, and 41.64 to $110.31 \mathrm{~g}$ of organic acids in $100 \mathrm{~g}$ fresh weight. The lowest content of total polyphenols showed C. speciosa 'Rubra' ( $57.84 \mathrm{~g} / \mathrm{kg}$ dry weight, $\mathrm{dw}$ ) while $C . \times$ superba 'Nicoline' $(170.38 \mathrm{~g} / \mathrm{kg} \mathrm{dw})$ exhibited the highest concentration of those compounds. In the phenolic compounds, polymeric procyanidin fraction predominated $(65 \%)$ with procyanidin B2, C1, and (-)-epicatechin the most abundant. The antioxidant capacity measured by ABTS assay was mainly formed by polymeric procyanidins and flavan-3-ols, which was confirmed by ABTS on-line profiling. Chaenomeles fruits showed high potential for inhibition of $\alpha$-glucosidase and pancreatic lipase. The analyzed cultivars displayed greater potential for acetylcholinesterase $(\mathrm{AChE})$ inhibition than for butyrylcholinesterase (BuChE). The data indicate that Chaenomeles fruits could be regarded as a promising source of bioactive functional food.
\end{abstract}

Keywords: Japanese quince; flowering quince; LC-PDA-QTOF-ESI-MS; $\alpha$-amylase; $\alpha$-glucosidase; pancreatic lipase; AChE; BuChE; 15-LOX; antioxidant capacity; ABTS on-line; AHC analysis

\section{Introduction}

Chaenomeles species belong to the Rosaceae family (Maloideae subfamily) and have been known widely in China for thousands of years. In Europe, interest in these fruits has been systematically growing over the last twenty years. The generic name is associated with the anatomy of the fruit, 
it comes from the Greek words "chainein" (divide, open) and "melon" (apple). The systematic affiliation and naming of Maule's quince were ordered only a dozen years ago and currently four basic species belong to the genus Chaenomeles, while in Poland the following three species are mainly grown: C. speciosa (Sweet) Nakai (flowering or Chinese quince), C. japonica (Thunb.) Lindl. (Japanese quince), and C. $\times$ superba (Frahm) Rehd. (intermediate quince) which is made from the last two because of the easy crossing within the species [1].

Flowering quince grows up to 2 to 3 meters in height, has spiny shoots, broad and green leaves on the edges, and dark red flowers. The fruits of this species are spherical, slightly elongated, yellow, and aromatic. The Japanese quince is a much lower shrub (1to $1.5 \mathrm{~m}$ tall) and more broadly spread. It has smaller, almost round leaves, and the flowers usually have an orange-red color. Yellow fruit with a round shape due to the intense aroma are most often recommended for preserves. Intermediate quince, formed from the aforementioned species, is most commonly found. It is very changeable in appearance, because it has many cultivars differing in height, shape, size of fruit, or the color of flowers (e.g., 'Crimson and Gold' blooms in red, and 'Jet Trail' in white).

Chaenomeles fruit has been widely used in traditional medicine of the Far East, which confirms their presence in the Pharmacopeia of the People's Republic of China (2010). It describes Fructus Chaenomeles speciosa, as a source of medicinal raw materials, but the fruit of other species also have medicinal properties [2]. In vitro and in vivo studies have confirmed the anti-inflammatory, analgesic, antispasmodic, antioxidant, immunoregulatory, and antibacterial effects of this species. The potential to use Japanese quince fruit in the treatment of Parkinson's disease has also been found [3]. Consumption of the fruit of the Chaenomeles genus has been recommended for the following: rheumatism, beri-beri disease, cholera, dysentery, and enterocolitis. In particular, Japanese quince products have been suggested in the therapy for stomach diseases, alleviation of diarrheal symptoms and vomiting, and also protective in liver diseases [1]. Gorlach et al. [4] proved that procyanidin extracted from Japanese quince have proapoptotic activity of HT-29 colon and Caco-2 large intestine carcinoma cells, where fractions containing higher proanthocyanidin oligomers are more active than that of the lower ones.

The aim of this study was to compare the following: (i) basic chemical composition (content of dry matter, soluble solid, ash, pectins, L-ascorbic acid, sugars, and organic acids, as well as tritable acidity and $\mathrm{pH}$ ); (ii) the content of bioactive compounds such as polyphenolics including polymeric procyanidins (identification by liquid chromatography coupled with photodiode array detector and quadrupole time-of-flight electrospray ionization mass spectrometry (LC-PDA-QTOF-ESI-MS) and quantification by ultra performance liquid chromatography-photodiode array detector-fluorescence detector (UPLC-PDA-FL); and (iii) in vitro biological activities (antioxidant, $\alpha$-amylase, $\alpha$-glucosidase, $\mathrm{AChE}, \mathrm{BuChE}$, and 15-LOX inhibition activity) in the nineteen cultivars of Chaenomeles fruits. Our secondary aim was to determine the relationships between the basic chemical composition, polyphenolic, and specific biological activities of selected species and cultivars of Chaenomeles fruits. It should be emphasized that this is the first such comprehensive work characterizing the chemical composition and biological activities including as many as 19 cultivars of three different species of Chaenomeles. The research literature contains no reports on the effects of Chaenomeles extracts on pancreatic lipase, AChE, BuChE, and 15-lipoxygenase inhibition activity. In addition, research on $\alpha$-amylase and $\alpha$-glucosidase activity of specific cultivars, described in this paper, have not been reported by the other authors.

\section{Materials and Methods}

\subsection{Plant Material and Sample Preparation}

Three different species and nineteen cultivars of Chaenomeles fruits were used for research. Fruit samples (C. $\times$ superba 'Crimson and Gold', 'Colour Trail', and 'Cameo'; C. japonica 'Red Joy', and C. speciosa 'Nivalis', and 'Rubra') were collected manually from bushes grown in a field trial 
established in 2016 at the experimental orchard at Wrocław $\left(51^{\circ} 07^{\prime} 02.0^{\prime \prime} \mathrm{N}, 17^{\circ} 04^{\prime} 25.0^{\prime \prime}\right.$ E). C. $\times$ superba 'Texas Scarlet', 'Nicoline', 'Andenken an Karl Ramcke', 'Pink Lady', 'Flocon Rose', 'Hollandia', and 'Jet Trail'; C. japonica 'Cido'; C. speciosa 'Simonii'; and new genotype (n1) were collected from an experimental field from the Research Institute of Horticulture in Skierniewice (51 $55^{\circ} 41.688^{\prime \prime} \mathrm{N}, 20^{\circ} 9^{\prime}$ 9.896" E). C. $\times$ superba wild and C. japonica wild \#1 and \#2 were collected from wild bushes located near the Centennial Hall in Wroclaw ( $51^{\circ} 6^{\prime} 26.548^{\prime \prime} \mathrm{N}, 17^{\circ} 4^{\prime} 56.782^{\prime \prime}$ E) in September 2018. Approximately $0.5 \mathrm{~kg}$ fruits (of each cultivar) were collected and then were washed with distilled water. The first part of the study included measurements on fresh fruits of dry matter, ash, soluble solids, $\mathrm{pH}$, titratable acidity, pectin, L-ascorbic acid, sugars, and organic acids content.The second part included freeze dried using a freeze drier (Christ Alpha 2-4; Braun Biotech Int., Melsungen, Germany) for $24 \mathrm{~h}$ at the pressure of 0.220 mbar. The samples were subsequently ground using a pestle and mortar to a fine powder and stored vacuum packed in a freezer at $-80^{\circ} \mathrm{C}$ until the analysis but no longer than 5 weeks.

\subsection{Extraction Procedure}

Methanol extracts for determination of polyphenolic compounds were prepared as follows: The freeze-dried powder of fruits $(\sim 1 \mathrm{~g})$ was vortexed for $1 \mathrm{~min}$ with $6 \mathrm{~mL}$ methanol/water/acetic acid/ascorbic acid (30:68:1:1, v/v/v/m), sonicated for $20 \mathrm{~min}$ (Sonic 6D; Polsonic, Warsaw, Poland) and left for 24 hours at $4{ }^{\circ} \mathrm{C}$. Then, the extract was sonicated again for $20 \mathrm{~min}$, and centrifuged at $19.000 \times g$ for $10 \mathrm{~min}$ at $4{ }^{\circ} \mathrm{C}$. Finally, the extract was filtred by $0.20 \mu \mathrm{m}$ hydrophilic PTFE membrane (Millex Simplicity Filter; Merck, Germany) and used for phenolic compounds identification by LC-PDA-QTOF-ESI-MS and quantification by UPLC-PDA. For the determination of antioxidant and in vitro biological activities, the same protocol as that described above was used, but a methanol/water $(80: 20, v / v)$ with $1 \%$ hydrochloric acid mixture was used for extraction.

\subsection{Physicochemical Analyses}

The dry matter was measured using a vacuum dryer (SPT-200; ZEAMiL Horyzont, Kraków, Poland) according to Turkiewiczet al. [5], while the soluble solids content was determined in fresh juices with are refractometer (Atago Rx 5000; Atago Co.Ltd., Kyoto, Japan) and expressed as ${ }^{\circ}$ Brix. Total ash content was performed as reported previously by Wojdyło et al. [6]. Pectin content was analyzed according to the Morris method described by Pijanowski et al. [7] and expressed as g per $100 \mathrm{~g}$ of fresh weight ( $\mathrm{fw}$ ). Titratable acidity was determined by titration aliquots of homogenate of fresh fruits by $0.1 \mathrm{~N} \mathrm{NaOH}$ to an end point of $\mathrm{pH} 8.1$ using an automatic $\mathrm{pH}$ titration system (pH-meter type IQ 150; Warsaw, Poland) and expressed as $\mathrm{g}$ of malic acid per $100 \mathrm{~g} f \mathrm{f}$. The $\mathrm{pH}$ was measured with the same equipment.

L-ascorbic acid was analyzed according to the HPLC method described previously by Wojdyło et al. [8], and expressed as milligrams per $100 \mathrm{~g}$ fw. Sugars were determined by HPLC-ELSD while organic acids by UPLC-PDA method as described previously by Wojdyło et al. [6]. All samples were assayed in triplicate and the results were expressed as g of total sugar content or $g$ of organic acid per $\mathrm{kg}$ of fw, respectively.

\subsection{Identification and Quantification of Phenolic Compounds by the LC-PDA-QTOF-ESI-MS and UPLC-PDA Methods}

Identification and quantification of polyphenols from Chaenomeles fruits was carried out using an Acquity UPLC system (Waters Corp., Milford, MA, USA) equipped with a photodiode detector (PDA) with binary solvent manager (Waters Corp., Milford, MA, USA) series with a mass detector G2 $\mathrm{Q} / \mathrm{TOF}$ Micro mass spectrometer (Waters, Manchester, UK) equipped with an electrospray ionization (ESI) source operating in negative modes. An Acquity UPLC BEH C18 column $(2.1 \times 100 \mathrm{~mm}, 1.7 \mu \mathrm{m}$; Waters Corporation, Milford, USA) at $30{ }^{\circ} \mathrm{C}$ was used to perform the chromatographic separation of $5 \mu \mathrm{L}$ of each sample. Elution at a flow rate of $0.42 \mathrm{~mL} / \mathrm{min}$ was completed within $15 \mathrm{~min}$ using a sequence of elution modes, linear gradients and isocratic. The mobile phase was composed of 
solvent A (4.5\% formic acid) and solvent B (acetonitrile). Samples were eluted according to a linear gradient: 0 to $12 \mathrm{~min}, 1 \%$ to $25 \% \mathrm{~B} ; 12$ to $12.5 \mathrm{~min}, 100 \% \mathrm{~B} ; 12.5$ to. $13.5 \mathrm{~min}, 1 \% \mathrm{~B}$; and, then, held constant to re-equilibrate the column. Analysis was carried out using full scan, data-dependent MS scanning from $\mathrm{m} / \mathrm{z} 100$ to 1700 . Leucine enkephalin was used as the mass reference compound, to ensure that mass was measured accurately, at a concentration of $500 \mathrm{pg} / \mu \mathrm{L}$. The mass spectrometer was operated in a negative ion mode and set to the base peak intensity (BPI) chromatograms and scaled to 12,400 counts per second (cps) $(=100 \%)$. The optimized MS conditions were as follows: capillary voltage of $2000 \mathrm{~V}$, cone voltage of $35 \mathrm{~V}$, source and desolvation temperature were of 100 and $250{ }^{\circ} \mathrm{C}$, respectively, and desolvation gas (nitrogen) flow rate of $300 \mathrm{~L} / \mathrm{h}$. Collision-induced fragmentation experiments were performed using argon as the collision gas, with voltage ramping cycles from 0.3 to $2 \mathrm{~V}$. The characterization of the single components was carried out via the retention time and the accurate molecular masses. Phenolic acids, flavan-3-ols and flavonols compound were optimized to their estimated molecular masses $[\mathrm{M}-\mathrm{H}]^{-}$in the negative mode before and after fragmentation. The data were collected by MassLynx ${ }^{\mathrm{TM}}$ 4.1 ChromaLynx Application Manager (Waters Corp., Milford, MA, USA) software.

For quantification, elution was the same gradient as LC-PDA-QTOF-ESI-MS analysis. The PDA spectra were measured over the wavelength range of 200 to $600 \mathrm{~nm}$ in steps of $2 \mathrm{~nm}$. The runs were monitored at the following wavelengths: flavan-3-ols at $280 \mathrm{~nm}$, phenolic acids at $320 \mathrm{~nm}$, and flavonols at $360 \mathrm{~nm}$. Retention times $\left(\mathrm{R}_{\mathrm{t}}\right)$ and spectra were compared with those of pure standards. Quantification was achieved by injection of solutions of known concentrations ranging from 0.05 to $5 \mathrm{mg} / \mathrm{mL}\left(R^{2} \leq 0.9998\right)$ made from (-)-epicatechin, (+)-catechin, procyanidin B1, B2, B3, and $\mathrm{C} 1$, chlorogenic acid, neochlorogenic acid, 3,5-di-caffeoylquinic acid, quercetin and kaempferol -3-O-glucoside, and -3-O-rutinoside. 4- $p$-Coumaroylquinic acid was expressed as caffeic acid. Acylated quercetin and kaempferol were expressed as quercetin and kaempferol-3-O-glucoside, respectively. All samples were assayed in triplicate and the results were expressed as g per kg of dry weight (dw).

\subsection{Quantification of Polymeric Procyanidins by the UPLC-PDA-FLMethod}

Analysis of polymeric procyanidins was performed by the phloroglucinolysis method as described previously by Wojdyłoet al. [8]. The analysis was carried out on a UPLC system Acquity (Waters Corp., Milford, MA, USA) consisting of a binary solvent manager and fluorescence detector (FL). The fluorescence detection was recorded at an excitation wavelength of $278 \mathrm{~nm}$ and an emission wavelength of $360 \mathrm{~nm}$. The calibration curves, which were based on peak area, were established using $(+)$-catechin, (-)-epicatechin, and procyanidin B1 after phloroglucinol reaction as (+)-catechin- and (-)-epicatechin-phloroglucinol adduct standards. All incubations were done in triplicate. Results were expressed as g per $\mathrm{kg}$ of $\mathrm{dw}$.

\subsection{Determination of Antioxidant and In Vitro Biological Activities}

Antioxidant activities were determined using the ABTS method described by Re et al. [9] and the FRAP method described by Benzie and Strain [10]. The ORAC assay was determined following the method previously described by Ou et al. [11]. All samples were assayed in triplicate and the results were expressed as $\mathrm{mM}$ of Trolox per $100 \mathrm{~g}$ of $\mathrm{dw}$.

The inhibition of $\alpha$-amylase, $\alpha$-glucosidase, pancreatic lipase acetylcholinesterase, and butyrylcholinesterase were measured as reported previously by Wojdyło et al. [12] and 15-lipoxygenase inhibition activity was measured using ferric oxidation of xylenol orange (FOX) assay previously described by Chung et al. [13].

All samples were assayed in triplicate and the results were expressed as $\mathrm{IC}_{50}(\mathrm{mg}$ of dried sample per $\mathrm{mL}$ of enzyme) or \% of inhibition. All spectrophotometric measurements were performed using a plate reader Synergy H1 (BioTek Instruments, Inc., Winooski, VT, USA). 


\subsection{Antioxidant On-Line Profiling by HPLC-PDA Coupled with Post-Column Derivatization with ABTS}

The antioxidant activity of individual HPLC peaks was measured as reported previously by Turkiewicz et al. [14] using an on-line HPLC antioxidant detector system. The detection wavelength was set at 280 and $734 \mathrm{~nm}$, while the injection volume of sample was $10 \mu \mathrm{L}$. The separation was achieved using CADENZA C18 column ( $75 \mathrm{~mm} \times 4.6 \mathrm{~mm}$ i.d., $3 \mu \mathrm{m}$; Tokyo, Japan) with a C18 guard column at $30^{\circ} \mathrm{C}$. The gradient elution solvent was formic acid solution (solvent $\mathrm{A}, 2 \%$ ) and acetonitrile (solvent $\mathrm{B}, 100 \%$ ) at a flow rate of $0.6 \mathrm{~mL} / \mathrm{min}, 0$ to $30 \mathrm{~min}, 2 \%$ to $40 \% \mathrm{~B}$, and up to $45 \mathrm{~min}$ column was recognition. ABTS radical cations were produced in accordance with the method described by Re et al. [9]. The second pump delivered the ABTS solution (at a flow rate of $0.2 \mathrm{~mL} / \mathrm{min}$ ) which was mixed with the mobile phase after the first PDA detector. The mixture was guided through PTFE reaction coil $\left(25 \mathrm{~m}\right.$ long, $0.25 \mathrm{~mm}$ internal diameter, at $\left.40^{\circ} \mathrm{C}\right)$ to a second UV detector, where decolorization of the mixture was detected as a negative peak at $734 \mathrm{~nm}$.

\subsection{Statistical Analysis}

Statistical analysis was conducted using XLSTAT2017, Data Analysis and Statistical Solution for Microsoft Excel (Addinsoft, Paris, France). Significant differences $(p \leq 0.05)$ between means were evaluated by one-way ANOVA and Tukey's test. Agglomerative hierarchical clustering (AHC) analysis was performed to highlight correlations.

\section{Results and Discussion}

\subsection{Physiochemical Analysis}

Table 1 shows basic chemical composition and physical properties of the analyzed Chaenomeles fruits. Dry matter content of the fruits varied significantly $(p \leq 0.05)$ from $10.09 \%$ (C. japonica $\mathrm{n} 1)$ to $20.40 \%$ (C. $\times$ superba wild). Thomas et al. [15] reported dry matter content of Japanese quince genotypes grown in Sweden and Lithuania as ranging from $10.60 \%$ to $11.70 \%$, while Tarko et al. [16] determined dry matter content at the level of $12.90 \%$. Lesińska [17] investigated dry matter in Japanese quince fruit grown in Poland and obtained results from 13\% to 18\% (average 15.5\%) depending on the harvest year. In addition, the key parameter affecting the dry matter content is sun exposure, the shortage of which results in lower dry weight, but also maturity stage, cultivar, climatic conditions, and agrotechnical techniques. Ash content of the analyzed Chaenomeles fruits was from $0.32 \%(C . \times$ superba 'Crimson and Gold') to $0.64 \%(C . \times$ superba 'Pink Lady') $(p \leq 0.05)$. The results are consistent with those obtained by Rubinskiene et al. [18], which indicates that the range of ash content in Japanese quince fruit is $0.38 \%$ to $0.46 \%$. The content of soluble solids (mainly sugars) is an important indicator of the quality of fruit. The sweet taste of fruits depends on the amount of soluble solid content (SSC), which plays an important role for fruit intended for processing, as well as those for direct consumption. The SSC in Chaenomeles fruits of selected species and cultivars was from 5.8 (C. speciosa 'Simonii') to $12.1^{\circ} \mathrm{Brix}(\mathrm{C}$. $\times$ superba wild) $(p \leq 0.05)$. Higher values of the SSC were recorded in the fruit of Japanese quince by Rubinskiene et al. [18], i.e., from 14 to $17^{\circ}$ Brix, while results similar to ours $\left(9.4^{\circ}\right.$ Brix $)$ were obtained by Tarko et al. [16] and Ros et al. [19], for 21 different genotypes of Chaenomeles fruits SSC ranged from 5.2 to $8.8^{\circ}$ Brix (average $7.1^{\circ}$ Brix). Fruits belonging to the genus Chaenomeles are considered rich in pectin compounds, which are located mainly in the fruit pulp. The source of pectin is mainly immature fruit $(0.85 \%$ to $1.28 \%$ ), because, during the ripening of fruit, pectin is partially transformed to monosaccharides. The average pectin content in fruits (1.4\% of fresh fruit) is equal to or sometimes higher than the values determined in apples $[1,15]$. The analyzed fruits showed a large variation in pectin content $(p \leq 0.05)$ and the results ranged from $0.65 \%$ (C. japonica $\mathrm{n} 1)$ to $1.72 \%(C$. $\times$ superba wild). Undoubtedly, the characteristic feature of Chaenomeles fruits is high titratable acidity (TA). For the fruit of $C$. japonica, C. speciosa, and C. $\times$ superba values of TA ranged from 3.11 (C. japonica 'Cido') to $6.16 \mathrm{~g}$ malic acid/100 $\mathrm{g}$ fresh weight $(\mathrm{fw})(\mathrm{C} . \times$ superba wild). Other authors reported acidity values for Japanese quince fruit in the range from 2.6 to $5.6 \mathrm{~g}$ of malic acid/100 $\mathrm{g} f \mathrm{f} \mathrm{[19]}$ and $4.10 \mathrm{~g}$ of malic 
$\mathrm{acid} / 100 \mathrm{~g} \mathrm{fw}$ [16]. These values outweigh the acidity of apple juice $(0.2$ to $0.7 \mathrm{~g}$ malic acid/ $100 \mathrm{~g} \mathrm{fw})$ and are comparable with lemon (5.0 to $9.0 \mathrm{~g}$ malic acid/100 g fw) [19]. Therefore, the fruits are classified as extremely acidic, unsuitable for direct consumption [19]. The high acidity of the Chaenomeles juice was accompanied by a low $\mathrm{pH}$ from 2.71 (C. $\times$ superba wild) to 2.99 (C. speciosa 'Simonii'). To confirm the results, Ros et al. [19] determined the $\mathrm{pH}$ of Chaenomeles fruits genotypes in the range 2.40-2.99 (average 2.60). For comparison, the $\mathrm{pH}$ of apple juice is 3.50 to 3.80 and lemon 2.00 to 2.30 [19].

Large variation $(p \leq 0.05)$ was found in the content of L-ascorbic acid. Among the taxa studied, the sample of $C$. $\times$ superba 'Hollandia 'had the highest amount of L-ascorbic acid (195.05 mg/100 $\mathrm{g}$ $\mathrm{fw}$ ) while C. speciosa 'Rubra' had the lowest amount ( $30.26 \mathrm{mg} / 100 \mathrm{~g} \mathrm{fw})$. For comparison, Ros et al. [19] determined the average content of L-ascorbic acid in Chaenomeles fruit at $128.26 \mathrm{mg} / 100 \mathrm{~g}$. Bieniasz et al. [20] studied the influence of storage and harvesting year on the content of vitamin $C$ in Japanese quince fruit. They obtained results of L-ascorbic acid content in nine Chaenomeles genotypes in the range of 90.0-243.0 and 73.1-172.6 mg/100 g of fresh fruit in two successive years of harvest, respectively. The obtained results are higher than for lemon $(50.4 \mathrm{mg} / 100 \mathrm{~g} \mathrm{fw})$, strawberry $(60.0$ $\mathrm{mg} / 100 \mathrm{~g} \mathrm{fw})$, and blackcurrant $(86.0 \mathrm{mg} / 100 \mathrm{~g} \mathrm{fw})$ [21].

The Chaenomeles fruits are characterized by an extremely low content of sugars in comparison with many other fruits. C. $\times$ superba 'Texas Scarlet' was the cultivar with the highest sugar content, $3.98 \mathrm{~g} / 100 \mathrm{~g} \mathrm{fw}(p \leq 0.05)$, while 'Jet Trail' ranked at the other end of the scale $(0.44 \mathrm{~g} / 100 \mathrm{~g} \mathrm{fw})$. The main identified saccharide was fructose, followed by sorbitol and glucose. Each one accounted for approximately $40.10 \%, 32.89 \%$, and $26.70 \%$ of the total identified sugars, respectively. Xylose was only found in two cultivars of C. $\times$ superba, 'Crimson and Gold' and 'Andenken an Karl Ramcke', in trace concentrations. For comparison, Hellín et al. [22] analyzed the sugar content in ten Chaenomeles genotypes grown in Sweden and Lithuania and found that the main sugars are fructose, glucose, sorbitol, and sucrose. The content of reducing sugars was similar to the values obtained in earlier studies but also the presence of sucrose, maltose, mannitol, stachyose, raffinose, rhamnose, and inositol was reported before [16,22-24]. Differences in the quantitative and qualitative composition may result from, among other reasons, the fact that during the analysis of the whole fruit, apart from sugars, the carbohydrate constituents of the structural polysaccharides of the Chaenomeles fruit cell wall are also determined, which does not occur during juice analysis. One of the indicators characterizing fruit quality is the ratio of fructose to glucose (fructose is more resistant to heating than glucose, which slows the browning process, e.g., during the manufacture of preserves and marmalades). In the analyzed fruits it was 1.5, while Lesińska [23] found this index for Japanese quince fruit equal to 1.8. In contrast, Tarko et al. [16] reported this ratio equal to 0.3. For comparison, in apples it is 1.8 and in pears 2.0 [23]. 
Table 1. Basic chemical composition of selected species and cvs. of Chaenomeles fruits.

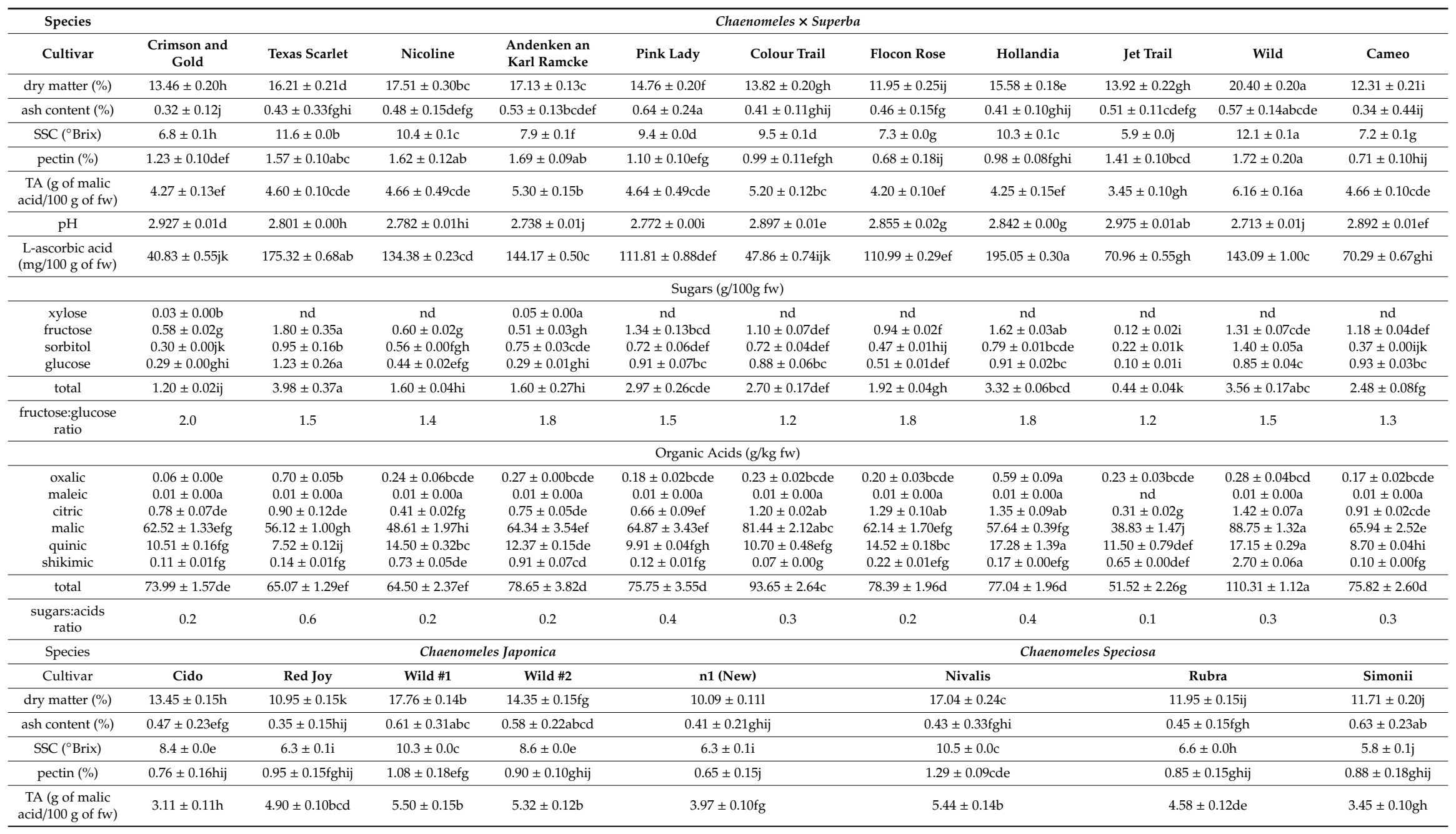


Table 1. Cont.

\begin{tabular}{|c|c|c|c|c|c|c|c|c|}
\hline \multirow{2}{*}{$\begin{array}{l}\text { Species } \\
\text { Cultivar }\end{array}$} & \multicolumn{8}{|c|}{ Chaenomeles $\times$ Superba } \\
\hline & $\begin{array}{l}\text { Crimson and } \\
\text { Gold }\end{array}$ & Texas Scarlet & Nicoline & $\begin{array}{l}\text { Andenken an } \\
\text { Karl Ramcke }\end{array}$ & Colour Trail & Flocon Rose & Jet Trail & Cameo \\
\hline $\mathrm{pH}$ & $2.867 \pm 0.01 \mathrm{fg}$ & $2.941 \pm 0.01 \mathrm{~cd}$ & $2.965 \pm 0.01 \mathrm{bc}$ & $2.966 \pm 0.01 \mathrm{bc}$ & $2.843 \pm 0.00 \mathrm{~g}$ & $2.862 \pm 0.00 \mathrm{~g}$ & $2.992 \pm 0.01 \mathrm{ab}$ & $2.994 \pm 0.00 \mathrm{a}$ \\
\hline $\begin{array}{l}\text { L-ascorbic acid } \\
(\mathrm{mg} / 100 \mathrm{~g} \text { of fw) }\end{array}$ & $132.33 \pm 0.35$ cde & $57.82 \pm 0.23 \mathrm{hij}$ & $101.72 \pm 0.21 \mathrm{f}$ & $114.13 \pm 0.21 \mathrm{def}$ & $91.19 \pm 0.57 \mathrm{fg}$ & $154.97 \pm 0.33 \mathrm{bc}$ & $30.26 \pm 0.20 \mathrm{k}$ & $53.6 \pm 0.09 \mathrm{hij}$ \\
\hline \multicolumn{9}{|c|}{ Sugars $(\mathrm{g} / 100 \mathrm{~g} \mathrm{fw})$} \\
\hline xylose & nd & nd & nd & nd & nd & nd & nd & nd \\
\hline fructose & $1.57 \pm 0.01 \mathrm{abc}$ & $0.18 \pm 0.02 \mathrm{i}$ & $1.11 \pm 0.04 \mathrm{def}$ & $1.02 \pm 0.01 \mathrm{ef}$ & \multirow{2}{*}{$0.62 \pm 0.03 \mathrm{~g}$} & $1.70 \pm 0.02 \mathrm{a}$ & $0.24 \pm 0.01 \mathrm{hi}$ & $0.25 \pm 0.02 \mathrm{hi}$ \\
\hline sorbitol & $0.66 \pm 0.01 \mathrm{efg}$ & $0.25 \pm 0.02 \mathrm{k}$ & $1.38 \pm 0.13 a$ & $0.92 \pm 0.12 b c$ & & \multirow{2}{*}{$\begin{array}{c}0.88 \pm 0.00 \mathrm{bcd} \\
1.21 \pm 0.01 \mathrm{a}\end{array}$} & $0.53 \pm 0.03 \mathrm{ghi}$ & $0.25 \pm 0.02 \mathrm{k}$ \\
\hline glucose & $1.07 \pm 0.03 \mathrm{ab}$ & $0.17 \pm 0.01 \mathrm{i}$ & $0.65 \pm 0.02 \mathrm{~d}$ & $0.62 \pm 0.02 \mathrm{de}$ & $0.42 \pm 0.01 \mathrm{fgh}$ & & $0.22 \pm 0.00 \mathrm{hi}$ & $0.15 \pm 0.01 \mathrm{i}$ \\
\hline $\begin{array}{c}\text { fructose:glucose } \\
\text { ratio }\end{array}$ & 1.5 & 1.1 & 1.7 & 1.6 & 1.5 & 1.4 & 1.1 & 1.6 \\
\hline \multicolumn{9}{|c|}{ Organic Acids ( $\mathrm{g} / \mathrm{kg} \mathrm{fw})$} \\
\hline oxalic & $0.13 \pm 0.02 \mathrm{cde}$ & $0.20 \pm 0.00 \mathrm{bcde}$ & $0.17 \pm 0.05 \mathrm{bcde}$ & $0.25 \pm 0.01 \mathrm{bcde}$ & $0.65 \pm 0.25 a$ & \multirow{2}{*}{$\begin{array}{c}0.26 \pm 0.00 \mathrm{bcde} \\
\text { nd }\end{array}$} & $0.09 \pm 0.01 \mathrm{de}$ & $0.32 \pm 0.08 \mathrm{bc}$ \\
\hline maleic & nd & $0.01 \pm 0.00 \mathrm{a}$ & $0.01 \pm 0.00 \mathrm{a}$ & $0.01 \pm 0.00 \mathrm{a}$ & $0.01 \pm 0.00 \mathrm{a}$ & & $0.01 \pm 0.00 \mathrm{a}$ & $0.01 \pm 0.00 \mathrm{a}$ \\
\hline citric & $0.30 \pm 0.06 \mathrm{~g}$ & $1.23 \pm 0.10 \mathrm{ab}$ & $1.35 \pm 0.04 \mathrm{ab}$ & $1.33 \pm 0.05 \mathrm{ab}$ & $0.94 \pm 0.17 \mathrm{~cd}$ & $1.16 \pm 0.09 \mathrm{bc}$ & $0.81 \pm 0.07 \mathrm{de}$ & $0.75 \pm 0.11 \mathrm{de}$ \\
\hline malic & $32.08 \pm 6.19 j$ & $79.51 \pm 3.82 \mathrm{bc}$ & $86.14 \pm 1.30 \mathrm{ab}$ & $86.04 \pm 0.78 \mathrm{ab}$ & $56.20 \pm 1.79 \mathrm{gh}$ & \multirow{2}{*}{$74.30 \pm 3.99 \mathrm{~cd}$} & $67.02 \pm 1.20 \mathrm{de}$ & $47.93 \pm 1.74 \mathrm{i}$ \\
\hline quinic & $9.05 \pm 0.76 \mathrm{ghi}$ & $9.15 \pm 0.36 \mathrm{ghi}$ & $14.22 \pm 0.80 \mathrm{bc}$ & $15.10 \pm 0.56 \mathrm{~b}$ & $13.09 \pm 0.20 \mathrm{~cd}$ & & $6.21 \pm 0.02 \mathrm{j}$ & $12.33 \pm 0.43 \mathrm{de}$ \\
\hline shikimic & $0.08 \pm 0.01 \mathrm{~g}$ & $1.12 \pm 0.08 \mathrm{bcd}$ & $1.34 \pm 0.56 \mathrm{bc}$ & $0.72 \pm 0.53 \mathrm{de}$ & $0.12 \pm 0.01 \mathrm{fg}$ & $\begin{array}{c}16.89 \pm 1.0 \mathrm{ab} \\
1.48 \pm 0.12 \mathrm{~b}\end{array}$ & $1.17 \pm 0.05 \mathrm{bcd}$ & $0.10 \pm 0.01 \mathrm{fg}$ \\
\hline total & $41.64 \pm 7.04 \mathrm{~h}$ & $91.21 \pm 4.36 \mathrm{c}$ & $103.23 \pm 2.58 \mathrm{ab}$ & $103.47 \pm 1.81 \mathrm{ab}$ & $71.01 \pm 1.52 \mathrm{de}$ & $94.09 \pm 5.26 \mathrm{bc}$ & $75.30 \pm 1.30 \mathrm{~d}$ & $61.45 \pm 2.37 \mathrm{f}$ \\
\hline $\begin{array}{l}\text { sugars:acids } \\
\text { ratio }\end{array}$ & 0.8 & 0.1 & 0.3 & 0.2 & 0.2 & 0.4 & 0.1 & 0.1 \\
\hline
\end{tabular}

nd, not detected; SSC, soluble solid content; TA, tritable acidity; fw, fresh weight. \pm Standard deviation, value in the same columns followed by different letters are significantly different at $p \leq 0.05$ according to Tukey's test. 
Contrary to sugars, Chaenomeles fruits contain very large amounts of organic acids. In the analyzed samples the following six organic acids were detected: oxalic, maleic, citric, malic, quinic, and shikimic (Table 1). Other typical organic acids normally found in fruits, such as succinic, fumaric, and tartaric acid, were not found in detectable amounts. The content of organic acids in Chaenomeles fruits differed between samples $(p \leq 0.05)$. Total content of organic acid ranged from 41.64 (C. japonica 'Cido') to $110.31 \mathrm{~g} / \mathrm{kg}$ fw (C. $\times$ superba wild). Malic acid, the main organic acid ( $81.94 \%$ of total acids), was present in the samples at concentrations from 32.08 to $88.75 \mathrm{~g} / \mathrm{kg}$ of fw, which is consistent with Hellín et al. [22]. The highest amount was found in a sample of $C . \times$ superba wild. The range of quinic acid $(15.63 \%$ of total acids) was $6.21-16.89 \mathrm{~g} / \mathrm{kg}$ fw. The remaining acids, i.e., citric, shikimic, oxalic, and maleic were in the minority and accounted for $1.20,0.89,0.34$, and $0.01 \%$, respectively, of the total amount of organic acids. Another parameter of fruit quality is the ratio of sugars to acids. For fruit intended for direct consumption, it is required that sugars must exceed acids ten-fold. In the case of the analyzed Chaenomeles fruits this ratio is only 0.3:1, and thus is even lower than among the fruits of sea buckthorn, wild growing trees, and shrubs or lemons, where this ratio is 1:1. Due to the high acidity, Chaenomeles fruits or juices are unsuitable for drinking without the addition of sweeteners. Additionally, for juices a better alternative seems to be the inoculation of the malolactic microorganism Oenococcus oeni, which transforms malic acid into lactic acid, characterized by lower acidity. In addition, malic acid is used in the food industry as an acidifying additive, and therefore Chaenomeles juice, like lemon juice, can be used as a natural acidifying agent in a wide range of food products $[19,22]$.

\subsection{Polyphenol Compounds}

A total of 15 polyphenol compounds were found in the nineteen cultivars of the three Chaenomeles species by using LC-PDA-QTOF-ESI-MS (Table 2). Structural formulas of selected phenolic compounds identified in Chaenomeles fruits are shown on Figure S1 (Supplementary Material). In the chromatogram profiles (Figure 1) obtained at $280 \mathrm{~nm}$, the labeled peaks 1 to 15 followed an elution order. Among these compounds, 13 were flavan-3-ols (monomers and procyanidins dimers, trimers, and tetramers) and two were caffeoylquinic acid derivatives.

Table 2. Identification of phenolic compounds in Chaenomeles fruits on example Chaenomeles $\times$ superba 'Texas Scarlet' by using liquid chromatography coupled with photodiode array detector and quadrupole time-of-flight electrospray ionization mass spectrometry (LC-PDA-QTOF-ESI-MS).

\begin{tabular}{|c|c|c|c|c|c|c|}
\hline Peak & Compound & $\mathbf{R}_{\mathrm{t}}(\min )$ & $\lambda_{\max }(\mathrm{nm})$ & $\begin{array}{l}\text { Molecular } \\
\text { Formula }\end{array}$ & $\begin{array}{c}\text { MS }[\mathbf{M}-\mathbf{H}]^{-} \\
(m / z)\end{array}$ & MS/MS $(m / z)$ \\
\hline 1 & Procyanidin B3 & 11.09 & 280 & $\mathrm{C}_{30} \mathrm{H}_{26} \mathrm{O}_{12}$ & 577.13 & $425.08 / 451.00 / 407.05 / 289.05$ \\
\hline 2 & (+)-Catechin & 12.53 & $240 / 280$ & $\mathrm{C}_{15} \mathrm{H}_{13} \mathrm{O}_{6}$ & 289.06 & 245.06/205.03/125.01 \\
\hline 3 & Procyanidin trimer & 12.79 & 280 & С $45 \mathrm{H} 37 \mathrm{O} 18$ & 865.21 & $577.13 / 425.08 / 289.06$ \\
\hline 4 & $\begin{array}{l}\text { 5-O-Caffeoylquinic acid } \\
\text { (chlorogenic) }\end{array}$ & 13.20 & $246 / 326$ & $\mathrm{C}_{22} \mathrm{H}_{27} \mathrm{O}_{14}$ & 353.08 & 191.04 \\
\hline 5 & $\begin{array}{l}\text { 4-O-Caffeoylquinic acid } \\
\text { (cryptochlorogenic) }\end{array}$ & 13.33 & $246 / 326$ & $\mathrm{C}_{22} \mathrm{H}_{27} \mathrm{O}_{14}$ & 353.08 & 191.04 \\
\hline 6 & Procyanidin trimer & 13.84 & 280 & С45H37O18 & 865.21 & $577.13 / 425.08 / 289.06$ \\
\hline 7 & Procyanidin B2 & 14.19 & 280 & $\mathrm{C}_{30} \mathrm{H}_{26} \mathrm{O}_{12}$ & 577.13 & $425.08 / 451.00 / 407.05 / 289.05$ \\
\hline 8 & Procyanidin dimer & 15.21 & 280 & $\mathrm{C}_{30} \mathrm{H}_{26} \mathrm{O}_{12}$ & 577.13 & $425.08 / 289.05$ \\
\hline 9 & (-)-Epicatechin & 15.58 & $240 / 280$ & $\mathrm{C}_{15} \mathrm{H}_{13} \mathrm{O}_{6}$ & 289.06 & $245.06 / 205.03 / 125.01$ \\
\hline 10 & Procyanidin dimer & 15.80 & 280 & $\mathrm{C}_{30} \mathrm{H}_{26} \mathrm{O}_{12}$ & 577.13 & $425.08 / 289.05$ \\
\hline 11 & Procyanidin C1 & 16.18 & 280 & $\mathrm{C} 45 \mathrm{H} 37 \mathrm{O} 18$ & 865.21 & $577.13 / 289.06 / 245.06 / 125.01$ \\
\hline 12 & Procyanidin tetramer & 16.79 & 280 & $\mathrm{C} 60 \mathrm{H} 49 \mathrm{O} 24$ & 1153.3 & $865.21 / 576.12 / 289.05$ \\
\hline 13 & Procyanidin tetramer & 17.00 & 280 & $\mathrm{C} 60 \mathrm{H} 49 \mathrm{O} 24$ & 1153.3 & $865.21 / 576.12 / 289.05$ \\
\hline 14 & Procyanidin dimer & 17.20 & 280 & $\mathrm{C}_{30} \mathrm{H}_{26} \mathrm{O}_{12}$ & 577.13 & $425.08 / 289.05$ \\
\hline 15 & Procyanidin dimer & 17.92 & 280 & $\mathrm{C}_{30} \mathrm{H}_{26} \mathrm{O}_{12}$ & 577.13 & $425.08 / 289.05$ \\
\hline
\end{tabular}

The $m / z$ values of flavan-3-ol ions were as follows: $[\mathrm{M}-\mathrm{H}]^{-} 289$ for monomer of $(+)$-catechin or (-)-epicatechin, and for B-type procyanidin dimer as $[\mathrm{M}-\mathrm{H}]^{-} 577$, trimer as $[\mathrm{M}-\mathrm{H}]^{-} 865$, and for tetramer as $[\mathrm{M}-\mathrm{H}]^{-} 1153[2,25]$. Six procyanidin dimers (peaks 1, 7, 8, 9, 14, and 15) were detected at different retention times $\left(\mathrm{R}_{\mathrm{t}}\right)$ in the electrospray-ionization quadrupole time-of-flight (ESI-QTOF) mass spectrometry in negative ion mode. All compounds gave the same $[\mathrm{M}-\mathrm{H}]^{-}$parental ion at $m / z 577.13$ in 
accordance with the molecular formula $\mathrm{C}_{30} \mathrm{H}_{26} \mathrm{O}_{12}$ [26]. Their molecular ions showed a fragment ion (MS/MS) at $m / z$ 425.08. In addition, each of these compounds had a fragmentation ion at $m / z 289.05$, which confirms that the procyanidins in Chaenomeles fruit are made of (+)-catechin and (-)-epicatechin units. Through analyzing the samples with standards and based on a comparison of $R_{t}$, it was found that peaks 1 and 7 are procyanidin B3 and B2, respectively, which is in accordance with Du et al. [2] and Teleszko and Wojdyło [27]. Moreover, the negative ESI-QTOF spectra of procyanidin B1 and procyanidin $\mathrm{B} 2$ gave $[\mathrm{M}-\mathrm{H}-170]^{-}$fragment ions at $\mathrm{m} / \mathrm{z} 407$ from the retro Diels-Alder $\mathrm{F}$ reaction of the heterocyclic ring and loss of $\mathrm{H}_{2} \mathrm{O}$ at $\mathrm{m} / \mathrm{z} 451\left([\mathrm{M}-\mathrm{H}-126]^{-}\right)$from cleavages between $\mathrm{C}_{4}-\mathrm{C}_{5}$ [28]. Therefore, peaks $8,10,14$ and 15 have been suggested to be procyanidin dimers [25]. Peak $2(\mathrm{~m} / z$ 289.06) yielded fragment ions at $m / z 245.06,205.03$, and 125.01, while peak 9 gave the same fragment ions. Due to the fact that stereoisomers could not be distinguished by mass spectrometry, the retention times have been compared with the standards, and those compounds have been assigned to $(+)$-catechin and (-)-epicatechin, respectively.

Moreover, according to Bravo et al. [29], the [M-H-44] ${ }^{-}$fragment at $\mathrm{m} / \mathrm{z} 245.06$ could result from the loss of a $\mathrm{CO}_{2}$ group or the loss of a $-\mathrm{CH}_{2}-\mathrm{CHOH}-$ group and the ion at $\mathrm{m} / \mathrm{z} 205.03$ is probably due to the loss of a flavonoid A-ring. The presence of an ion at $m / z 125.01$ is considered to be diagnostic for the presence of two $(-\mathrm{OH})$ groups on the A-ring of flavan-3-ols [30]. The elution order of procyanidin monomers, dimers, and trimers was procyanidin B3 $<(+)$-catechin $<$ procyanidin $\mathrm{B} 2<(-)$-epicatechin $<$ procyanidin $\mathrm{C} 1$. Whereas, peaks 3 and 6 with a precursor ion at $\mathrm{m} / \mathrm{z} 865.21$ and identical molecular formula $\mathrm{C}_{45} \mathrm{H}_{37} \mathrm{O}_{18}$ were designated as procyanidin trimers. Peak $11\left(\mathrm{R}_{\mathrm{t}}=16.18 \mathrm{~min}\right)$ exhibited a deprotonated molecule at $m / z 865.21$ and a MS/MS fragment at $m / z 577.13,289.06,245.06$, and 125.01. The comparative analysis with standards confirmed that this signal came from procyanidin $\mathrm{C} 1$. Additionally, this compound was reported in Japanese quince before by Teleszko and Wojdyło [27] and Lewandowska et al. [31]. Finally, peaks 12 and 13 at $\mathrm{Rt}=16.79$ and $17.00 \mathrm{~min}$, respectively, with the molecular ion at $\mathrm{m} / \mathrm{z} 1153.3$ and molecular formula $\mathrm{C} 60 \mathrm{H} 49 \mathrm{O} 24$, have been proposed to be procyanidin tetramers.

With regards to caffeoylquinic acid derivatives, two compounds were detected at $\mathrm{Rt}=13.20 \mathrm{~min}$ and $\mathrm{Rt}=13.33 \mathrm{~min}$. Peaks 4 and 5, with the identical molecular formula C22H27O14, demonstrated the same UV absorption bands and the same $[\mathrm{M}-\mathrm{H}]^{-}$at $\mathrm{m} / \mathrm{z}$ 353.08. Moreover, a product ion [M-H-162 $]^{-}$at $\mathrm{m} / \mathrm{z}$ 191.04, which was ascribed to quinic acid, was also the same for both compounds. On the basis of the correct MS and MS/MS data but also the literature [5,26,31], these compounds were designated as 5-O-caffeoylquinic acid (chlorogenic) and 4-O-caffeoylquinic acid (cryptochlorogenic), respectively.

The content of each polyphenol compound was calculated using UPLC-PDA analysis. The flavan-3-ol content including (+)-catechin, (-)-epicatechin, and procyanidin oligomers accounts for $96.02 \%$ to $99.85 \%$ of all phenolic compounds. This indicates clearly that procyanidins were the main polyphenol compounds in Chaenomeles fruits. Generally, there were three main compounds (procyanidin B2, (-)-epicatechin, and procyanidin $\mathrm{C} 1$ ) in the analyzed species and cultivars of Chaenomeles (Table 3).

Total phenolic content, calculated as the sum of individual phenolic compounds, varied significantly between genotypes $(p \leq 0.05)$, with $C . \times$ superba 'Nicoline' displaying the highest $(170.38 \mathrm{~g} / \mathrm{kg} \mathrm{dw})$, and C. speciosa 'Rubra' the lowest content $(57.84 \mathrm{~g} / \mathrm{kg} \mathrm{dw})$. Procyanidin B2 was the compound present in the largest amount, in the range from 3.39 (C. japonica 'Red Joy') to $18.16 \mathrm{~g} / \mathrm{kg}$ $\mathrm{dw}(C . \times$ superba 'Nicoline'). Analyzing the content of (+)-catechin and (-)-epicatechin in particular species, $C$. $\times$ superba contained 0.27 to 1.07 and 2.35 to $7.68 \mathrm{~g} / \mathrm{kg} \mathrm{dw}, C$. japonica 0.22 to 0.86 and 1.77 to $4.93 \mathrm{~g} / \mathrm{kg} \mathrm{dw}$ while $C$. speciosa contained 0.69 to 0.99 and 1.97 to $4.99 \mathrm{~g} / \mathrm{kg} \mathrm{dw}$, respectively. The content of polymeric procyanidins in all the tested genotypes ranged from 34.60 (C. $\times$ superba 'Color Trail') to $109.67 \mathrm{~g} / \mathrm{kg}$ dw (C. $\times$ superba 'Colour Trail'), with an average of $63.27 \mathrm{~g} / \mathrm{kg} \mathrm{dw}$. The degree of polymerization (DP) ranged from $2.43($ C. $\times$ superba 'Colour Trail') to $4.25(C . \times$ superba 'Pink Lady'), indicating that the analyzed flavan-3-ols were oligomers $(2<\mathrm{DP}<10)$ with a low degree of polymerization. Moreover, the low DP in the Chaenomeles fruit causes them to not be astringent 
and bitter, such as chokeberry, which also contains significant amounts of procyanidin compounds but with a much higher degree of polymerization [32]. Total phenolic content, as well as polymeric proanthocyanidin concentrations, in this study, were higher than reported by Du et al. [2] and Teleszko and Wojdyło [27]. C. $\times$ superba 'Cameo' accumulated the greatest amounts of phenolic acids $(3.30 \mathrm{~g} / \mathrm{kg}$ $\mathrm{dw})$, and in 'Cido' their content was the lowest $(0.15 \mathrm{~g} / \mathrm{kg} \mathrm{dw})$. Additionally, 4-O-caffeoylquinic acid (cryptochlorogenic) was absent in some samples, i.e., C. $\times$ superba 'Andenken an Karl Ramcke', 'Pink Lady', wild, C. japonica wild \#2, and C. speciosa 'Rubra'.
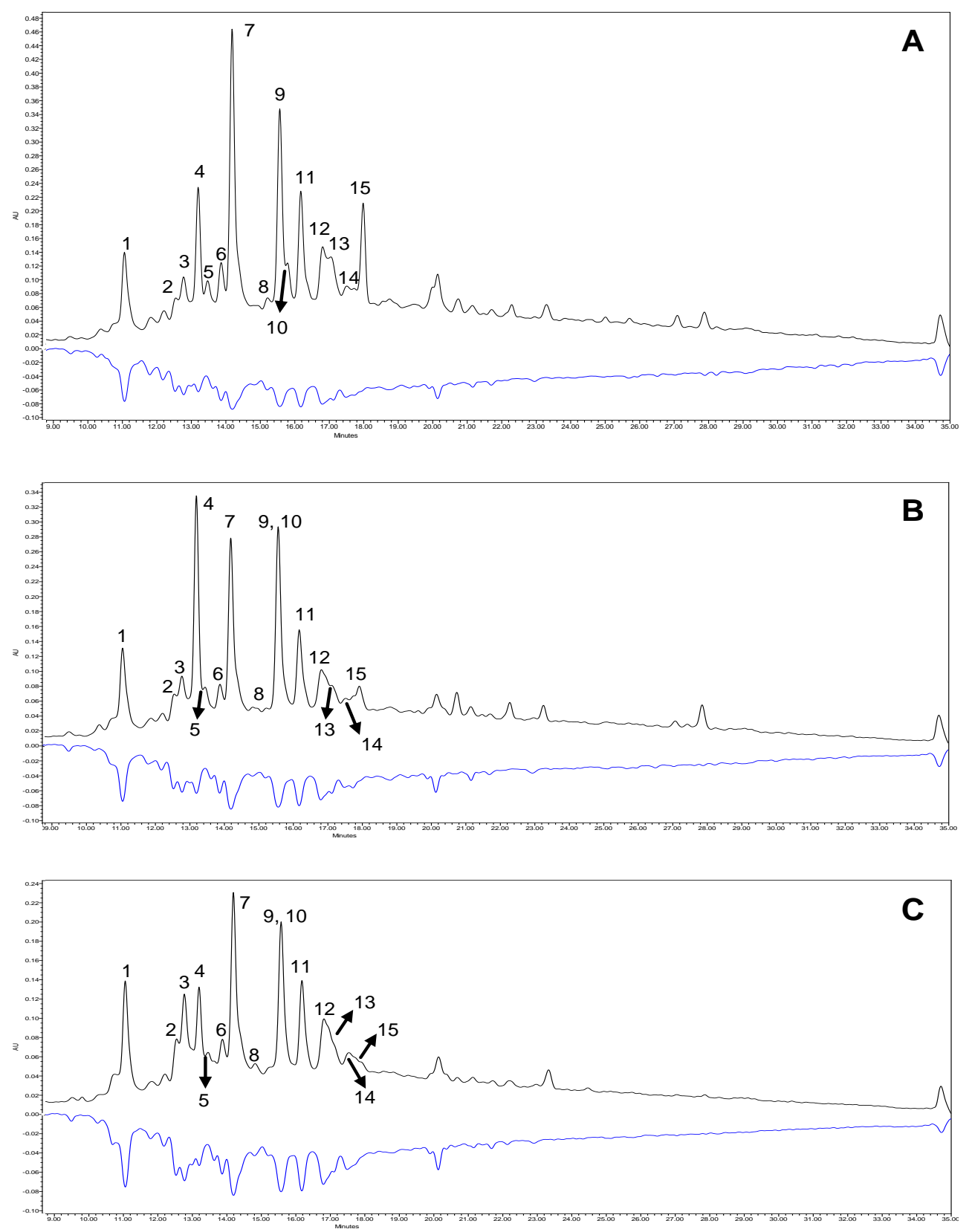

Figure 1. Segment (9.0 to $35.0 \mathrm{~min}$ ) of chromatographic profiles obtained before and after the derivatization process using the ABTS reagent in samples of Chaenomeles $\times$ superba 'Texas Scarlet' (A), Chaenomeles $\times$ superba 'Cameo' (B), and Chaenomeles speciosa 'Nivalis' (C). Peak number identities are displayed in Table 2. 
Table 3. Content of phenolic compounds $(\mathrm{g} / \mathrm{kg} \mathrm{dw})$ invarious species and cvs. of Chaenomeles fruits.

\begin{tabular}{|c|c|c|c|c|c|c|c|c|c|c|c|}
\hline \multirow[b]{2}{*}{ Peak no } & \multicolumn{11}{|c|}{ Chaenomeles $\times$ Superba } \\
\hline & $\begin{array}{l}\text { Crimson and } \\
\text { Gold }\end{array}$ & Texas Scarlet & Nicoline & $\begin{array}{l}\text { Andenken an } \\
\text { Karl Ramcke }\end{array}$ & Pink Lady & Colour Trail & Flocon Rose & Hollandia & Jet Trail & Wild & Cameo \\
\hline \multicolumn{12}{|c|}{ Phenolic acids } \\
\hline 4 & $0.43 \pm 0.15 \mathrm{ef}$ & $1.68 \pm 0.20 \mathrm{bc}$ & $1.34 \pm 0.21 \mathrm{~cd}$ & $1.35 \pm 0.10 \mathrm{~cd}$ & $0.79 \pm 0.13 \mathrm{de}$ & $0.23 \pm 0.08 \mathrm{ef}$ & $1.65 \pm 0.27 b c$ & $1.08 \pm 0.11 \mathrm{~cd}$ & $1.12 \pm 0.19 \mathrm{~cd}$ & $3.04 \pm 0.21 \mathrm{a}$ & $3.05 \pm 0.15 \mathrm{a}$ \\
\hline 5 & $0.46 \pm 0.12 \mathrm{bc}$ & $0.35 \pm 0.10 \mathrm{bc}$ & $0.04 \pm 0.00 c$ & nd & nd & $0.36 \pm 0.08 \mathrm{bc}$ & $0.41 \pm 0.22 \mathrm{bc}$ & $0.45 \pm 0.11 \mathrm{bc}$ & $0.06 \pm 0.00 c$ & nd & $0.25 \pm 0.14 \mathrm{bc}$ \\
\hline Sum & $0.89 \pm 0.15 \mathrm{ef}$ & $2.03 \pm 0.20 \mathrm{bc}$ & $1.38 \pm 0.00 \mathrm{de}$ & $1.35 \pm 0.31 \mathrm{de}$ & $0.79 \pm 0.20 \mathrm{ef}$ & $0.59 \pm 0.10 \mathrm{fg}$ & $2.06 \pm 0.33 \mathrm{bc}$ & $1.53 \pm 0.18 \mathrm{~cd}$ & $1.18 \pm 0.27 \mathrm{def}$ & $3.04 \pm 0.11 \mathrm{a}$ & $3.30 \pm 0.19 \mathrm{a}$ \\
\hline \multicolumn{12}{|c|}{ Flavan-3-ols } \\
\hline 1 & $0.28 \pm 0.08 \mathrm{i}$ & $2.86 \pm 0.22 \mathrm{a}$ & $1.85 \pm 0.21 \mathrm{cde}$ & $1.47 \pm 0.18 \mathrm{efg}$ & $0.65 \pm 0.09 \mathrm{hi}$ & $1.00 \pm 0.12 \mathrm{gh}$ & $2.02 \pm 0.44 \mathrm{bcde}$ & $1.66 \pm 0.36 \mathrm{def}$ & $1.76 \pm 0.15 \mathrm{cde}$ & $1.75 \pm 0.27 \mathrm{cde}$ & $2.75 \pm 0.22 \mathrm{a}$ \\
\hline 2 & $0.27 \pm 0.10 \mathrm{de}$ & $0.29 \pm 0.11 \mathrm{cde}$ & $0.42 \pm 0.08 \mathrm{bcde}$ & $0.37 \pm 0.10 \mathrm{cde}$ & $0.42 \pm 0.15 \mathrm{bcde}$ & $0.75 \pm 0.15 \mathrm{abcde}$ & $0.62 \pm 0.22 \mathrm{abcde}$ & $0.69 \pm 0.19 \mathrm{abcde}$ & $1.07 \pm 0.08 \mathrm{a}$ & $0.86 \pm 0.31 \mathrm{abcd}$ & $0.86 \pm 0.28 \mathrm{abcd}$ \\
\hline 3 & nd & $2.86 \pm 0.44 \mathrm{a}$ & $2.64 \pm 0.39 \mathrm{a}$ & $2.40 \pm 0.30 \mathrm{ab}$ & nd & $0.40 \pm 0.18 \mathrm{f}$ & $1.07 \pm 0.19 \mathrm{de}$ & $0.88 \pm 0.24 \mathrm{def}$ & $0.94 \pm 0.09 \mathrm{def}$ & $1.16 \pm 0.12 \mathrm{de}$ & $1.97 \pm 0.33 \mathrm{bc}$ \\
\hline 6 & $1.59 \pm 0.18 c$ & $2.33 \pm 0.28 \mathrm{~b}$ & $3.00 \pm 0.30 \mathrm{a}$ & $2.28 \pm .21 \mathrm{~b}$ & $1.03 \pm 0.18 \mathrm{cde}$ & $0.87 \pm 0.22 \mathrm{de}$ & $0.91 \pm 0.10 \mathrm{de}$ & $1.48 \pm 0.19 \mathrm{~cd}$ & $2.73 \pm 0.28 \mathrm{ab}$ & $1.46 \pm 0.17 \mathrm{~cd}$ & $1.39 \pm 0.19 \mathrm{cde}$ \\
\hline 7 & $10.92 \pm 1.21 \mathrm{~d}$ & $13.40 \pm 1.30 \mathrm{c}$ & $18.16 \pm 1.02 \mathrm{a}$ & $14.19 \pm 1.00 \mathrm{~b}$ & $5.53 \pm 0.50 \mathrm{i}$ & $7.90 \pm 0.67 \mathrm{f}$ & $5.74 \pm 0.78 \mathrm{hi}$ & $9.29 \pm 0.62 \mathrm{e}$ & $14.72 \pm 1.05 \mathrm{~b}$ & $9.60 \pm 0.77 \mathrm{e}$ & $8.24 \pm 0.46 \mathrm{f}$ \\
\hline 8 & $1.27 \pm 0.62 \mathrm{cde}$ & $2.59 \pm 0.80 \mathrm{a}$ & $2.55 \pm 0.55 a$ & $1.84 \pm 0.42 b c$ & $1.34 \pm 0.42 \mathrm{cde}$ & $1.28 \pm 0.33 \mathrm{cde}$ & $1.20 \pm 0.27 \mathrm{de}$ & $1.34 \pm 0.19 \mathrm{cde}$ & $2.16 \pm 0.55 \mathrm{ab}$ & $1.17 \pm 0.31 \mathrm{def}$ & $1.42 \pm 0.41 \mathrm{~cd}$ \\
\hline 9 & $6.8 \pm 0.99 \mathrm{bc}$ & $5.03 \pm 0.55 \mathrm{~d}$ & $6.99 \pm 0.89 b$ & $7.68 \pm 0.77 a$ & $2.35 \pm 0.60 \mathrm{gh}$ & $5.02 \pm 0.63 \mathrm{~d}$ & $2.79 \pm 0.49 \mathrm{~g}$ & $4.35 \pm 0.55 f$ & $6.30 \pm 0.68 c$ & $4.59 \pm 0.70 \mathrm{def}$ & $4.93 \pm 0.66 \mathrm{def}$ \\
\hline 10 & nd & $0.91 \pm 0.10 \mathrm{a}$ & $0.48 \pm 0.25 \mathrm{abc}$ & nd & $0.23 \pm 0.11 \mathrm{c}$ & nd & $0.51 \pm 0.21 \mathrm{abc}$ & $0.65 \pm 0.10 \mathrm{abc}$ & $0.65 \pm 0.10 \mathrm{abc}$ & nd & $0.79 \pm 0.13 \mathrm{abc}$ \\
\hline 11 & $3.90 \pm 0.54 \mathrm{de}$ & $5.88 \pm 0.52 c$ & $7.58 \pm 1.12 \mathrm{a}$ & $6.71 \pm 0.66 \mathrm{~b}$ & $1.87 \pm 0.28 \mathrm{ij}$ & $3.05 \pm 0.65 \mathrm{fgh}$ & $3.16 \pm 0.33 f \mathrm{fg}$ & $4.12 \pm 0.33 \mathrm{de}$ & $5.84 \pm 0.74 \mathrm{c}$ & $4.31 \pm 0.56 \mathrm{gh}$ & $4.20 \pm 0.60 \mathrm{de}$ \\
\hline 12 & $2.39 \pm 0.10 \mathrm{fgh}$ & $3.78 \pm 0.25 b c$ & $4.36 \pm 0.85 a \mathrm{ab}$ & $3.61 \pm 0.33 \mathrm{~cd}$ & $1.29 \pm 0.00 \mathrm{jk}$ & $1.81 \pm 0.31$ hij & $2.26 \pm 0.55 \mathrm{gh}$ & $2.41 \pm 0.33 \mathrm{fgh}$ & $3.07 \pm 0.59 \mathrm{de}$ & $2.05 \pm 0.27 \mathrm{hi}$ & $2.05 \pm 0.55 \mathrm{ghi}$ \\
\hline 13 & $4.28 \pm 0.87 \mathrm{~d}$ & $6.03 \pm 0.54 \mathrm{bc}$ & $7.12 \pm 0.42 \mathrm{a}$ & $5.81 \pm 0.77 c$ & $2.68 \pm 0.28 \mathrm{gh}$ & $3.70 \pm 0.44 \mathrm{de}$ & $2.44 \pm 0.36 \mathrm{ghi}$ & $3.49 \pm 0.50 \mathrm{e}$ & $6.60 \pm 0.45 \mathrm{ab}$ & $3.38 \pm 0.22 \mathrm{ef}$ & $2.87 \pm 0.85 \mathrm{fg}$ \\
\hline 14 & $0.61 \pm 0.55 \mathrm{fgh}$ & $1.58 \pm 0.30 c$ & $2.33 \pm 0.54 \mathrm{~b}$ & $1.40 \pm 0.26 \mathrm{cde}$ & $0.62 \pm 0.40 \mathrm{fgh}$ & nd & $0.93 \pm 0.58$ defgh & $0.90 \pm 0.63$ efgh & $1.14 \pm 0.28 \mathrm{cdef}$ & $1.12 \pm 0.24 \mathrm{cdefg}$ & $0.67 \pm 0.00 \mathrm{fgh}$ \\
\hline 15 & $2.80 \pm 0.60 \mathrm{c}$ & $4.67 \pm 0.47 \mathrm{a}$ & $1.85 \pm 0.32 \mathrm{efg}$ & $1.49 \pm 0.40 \mathrm{fgh}$ & $0.93 \pm 0.35 \mathrm{hi}$ & $0.48 \pm 0.09 \mathrm{ij}$ & $2.20 \pm 0.45 \mathrm{cde}$ & $3.55 \pm 0.27 \mathrm{~b}$ & $2.08 \pm 0.65 \mathrm{def}$ & $1.17 \pm 0.33 \mathrm{~h}$ & $1.39 \pm 0.14 \mathrm{gh}$ \\
\hline Sum & $35.11 \pm 1.18 \mathrm{~d}$ & $52.21 \pm 1.33 \mathrm{~b}$ & $59.33 \pm 2.15 a$ & $49.25 \pm 1.22 \mathrm{c}$ & $18.94 \pm 1.66 j$ & $26.26 \pm 0.99 h \mathrm{hi}$ & $25.85 \pm 1.15 \mathrm{hi}$ & $34.81 \pm 1.66 \mathrm{de}$ & $49.04 \pm 1.44 \mathrm{c}$ & $32.62 \pm 2.03 \mathrm{efg}$ & $33.53 \pm 1.88 \mathrm{def}$ \\
\hline $\begin{array}{l}\text { Polymeric } \\
\text { procyanidins }\end{array}$ & $\mathrm{s} 51.73 \pm 0.99 \mathrm{~g}$ & $100.47 \pm 1.33 \mathrm{~b}$ & $109.67 \pm 1.11 \mathrm{a}$ & $88.37 \pm 1.15 c$ & $74.33 \pm 2.33 \mathrm{~d}$ & $34.60 \pm 1.21 \mathrm{k}$ & $48.46 \pm 1.65 \mathrm{hi}$ & $63.69 \pm 1.35 f$ & $73.53 \pm 0.87 d$ & $68.15 \pm 0.98 \mathrm{e}$ & $54.04 \pm 2.22 \mathrm{~g}$ \\
\hline DP & 2.91 & 3.77 & 3.98 & 3.44 & 4.25 & 2.43 & 3.41 & 3.45 & 3.24 & 3.80 & 3.35 \\
\hline Total & $87.73 \pm 2.22 j$ & $154.71 \pm 3.00 \mathrm{~b}$ & $170.38 \pm 1.25 a$ & $138.97 \pm 1.98 \mathrm{c}$ & $94.06 \pm 1.98 \mathrm{~h}$ & $61.45 \pm 1.24 \mathrm{~m}$ & $76.37 \pm 1.56 \mathrm{k}$ & $100.03 \pm 1.54 \mathrm{f}$ & $123.75 \pm 1.88 \mathrm{~d}$ & $103.81 \pm 2.22 \mathrm{e}$ & $90.87 \pm 1.78 \mathrm{i}$ \\
\hline
\end{tabular}


Table 3. Cont.

\begin{tabular}{|c|c|c|c|c|c|c|c|c|}
\hline \multirow{2}{*}{ Peak no } & \multicolumn{5}{|c|}{ Chaenomeles Japonica } & \multicolumn{3}{|c|}{ Chaenomeles Speciosa } \\
\hline & Cido & Red Joy & Wild \#1 & Wild \#2 & n1 (New) & Nivalis & Rubra & Simonii \\
\hline \multicolumn{9}{|c|}{ Phenolic acids } \\
\hline 4 & $0.09 \pm 0.02 \mathrm{f}$ & $1.07 \pm 0.17 \mathrm{~cd}$ & $0.31 \pm 0.15 \mathrm{ef}$ & $1.15 \pm 0.10 \mathrm{~cd}$ & $2.12 \pm 0.20 \mathrm{~b}$ & $2.05 \pm 0.26 \mathrm{~b}$ & $1.29 \pm 0.15 \mathrm{~cd}$ & $0.25 \pm 0.05 \mathrm{ef}$ \\
\hline 5 & $0.06 \pm 0.01 \mathrm{c}$ & $0.04 \pm 0.01 \mathrm{c}$ & $0.70 \pm 0.22 \mathrm{~b}$ & nd & $0.28 \pm 0.16 \mathrm{bc}$ & $0.19 \pm 0.10 \mathrm{c}$ & nd & $2.80 \pm 0.33 a$ \\
\hline Sum & $0.15 \pm 0.05 \mathrm{~g}$ & $1.11 \pm 0.21 \mathrm{def}$ & $1.01 \pm 0.06 \mathrm{def}$ & $1.15 \pm 0.15 \mathrm{def}$ & $2.40 \pm 0.17 \mathrm{~b}$ & $2.24 \pm 0.25 b$ & $1.29 \pm 0.10 \mathrm{de}$ & $3.05 \pm 0.44 a$ \\
\hline \multicolumn{9}{|c|}{ Flavan-3-ols } \\
\hline 1 & $0.38 \pm 0.10 \mathrm{i}$ & $1.88 \pm 0.19 \mathrm{cde}$ & $0.48 \pm 0.11 \mathrm{hi}$ & $1.09 \pm 0.17 \mathrm{fgh}$ & $2.29 \pm 0.38 \mathrm{abc}$ & $2.08 \pm 0.30 \mathrm{bcd}$ & $2.51 \pm 0.50 \mathrm{ab}$ & $0.37 \pm 0.14 \mathrm{i}$ \\
\hline 2 & $0.39 \pm 0.13$ cde & $0.71 \pm 0.19$ abcde & $0.22 \pm 0.13 \mathrm{e}$ & $0.56 \pm 0.14 \mathrm{abcde}$ & $0.86 \pm 0.21 \mathrm{abc}$ & $0.69 \pm 0.38 \mathrm{abcde}$ & $0.99 \pm 0.39 \mathrm{ab}$ & $0.81 \pm 0.25 \mathrm{abcd}$ \\
\hline 3 & nd & $1.04 \pm 0.24 \mathrm{de}$ & nd & $0.75 \pm 0.28 \mathrm{ef}$ & $1.20 \pm 0.19 \mathrm{de}$ & $1.37 \pm 0.26 \mathrm{~d}$ & $1.40 \pm 0.30 \mathrm{~cd}$ & nd \\
\hline 6 & $2.23 \pm 0.15 b$ & $0.84 \pm 0.20 \mathrm{e}$ & $1.17 \pm 0.26 \mathrm{cde}$ & $0.91 \pm 0.15 \mathrm{de}$ & $1.34 \pm 0.08 \mathrm{cde}$ & $1.09 \pm 0.33 \mathrm{cde}$ & $1.13 \pm 0.16 \mathrm{cde}$ & $2.32 \pm 0.47 \mathrm{~b}$ \\
\hline 7 & $11.40 \pm 0.99 \mathrm{~d}$ & $3.39 \pm 0.96 j$ & $6.19 \pm 0.54 \mathrm{~h}$ & $5.36 \pm 0.66 \mathrm{i}$ & $8.40 \pm 0.72 \mathrm{f}$ & $7.15 \pm 0.60 \mathrm{~g}$ & $3.80 \pm 0.58 \mathrm{j}$ & $8.49 \pm 0.50 \mathrm{f}$ \\
\hline 8 & $1.57 \pm 0.50 \mathrm{bcd}$ & $0.48 \pm 0.33 \mathrm{~g}$ & $1.09 \pm 0.44 \mathrm{defg}$ & $0.77 \pm 0.20 \mathrm{efg}$ & $1.57 \pm 0.00 \mathrm{bcd}$ & $1.11 \pm 0.24 \mathrm{def}$ & $0.56 \pm 0.10 \mathrm{fg}$ & nd \\
\hline 9 & $4.37 \pm 0.22 \mathrm{f}$ & $1.77 \pm 0.11 \mathrm{~h}$ & $4.40 \pm 0.43 \mathrm{ef}$ & $2.31 \pm 0.39 \mathrm{gh}$ & $2.92 \pm 0.18 \mathrm{~g}$ & $2.88 \pm 0.52 \mathrm{~g}$ & $1.97 \pm 0.12 \mathrm{~h}$ & $4.99 \pm 0.12 \mathrm{de}$ \\
\hline 10 & $0.36 \pm 0.09 \mathrm{abc}$ & $0.41 \pm 0.20 \mathrm{abc}$ & $0.32 \pm 0.15 b c$ & nd & $0.53 \pm 0.22 \mathrm{abc}$ & $0.42 \pm 0.29 \mathrm{abc}$ & $0.43 \pm 0.08 \mathrm{abc}$ & $0.83 \pm 0.00 \mathrm{ab}$ \\
\hline 11 & $4.05 \pm 0.61 \mathrm{de}$ & $1.54 \pm 0.88 \mathrm{j}$ & $2.61 \pm 0.71 \mathrm{gh}$ & $2.43 \pm 0.70 \mathrm{hi}$ & $3.94 \pm 0.59 \mathrm{de}$ & $3.63 \pm 0.20 \mathrm{ef}$ & $1.75 \pm 0.55 j$ & $2.79 \pm 0.80 \mathrm{gh}$ \\
\hline 12 & $0.49 \pm 0.141$ & $0.39 \pm 0.001$ & $3.21 \pm 0.27 \mathrm{cde}$ & $1.17 \pm 0.40 \mathrm{k}$ & $2.67 \pm 0.00$ efg & $4.68 \pm 0.33 \mathrm{a}$ & $1.58 \pm 0.22 \mathrm{ijk}$ & $2.96 \pm 0.47 \mathrm{ef}$ \\
\hline 13 & $2.41 \pm 0.35 \mathrm{ghi}$ & $0.89 \pm 0.61 \mathrm{j}$ & $2.16 \pm 0.33 \mathrm{hi}$ & $1.91 \pm 0.54 \mathrm{i}$ & $3.45 \pm 0.96 \mathrm{ef}$ & $2.86 \pm 0.46 \mathrm{fg}$ & $0.82 \pm 0.28 \mathrm{j}$ & $2.55 \pm 0.27 \mathrm{gh}$ \\
\hline 14 & $4.74 \pm 0.19 a$ & $0.87 \pm 0.18$ efgh & $0.56 \pm 0.11$ fghi & $0.54 \pm 0.27 \mathrm{ghi}$ & $0.72 \pm 0.33 \mathrm{fgh}$ & $1.50 \pm 0.21 \mathrm{~cd}$ & $0.38 \pm 0.20 \mathrm{hi}$ & $0.39 \pm 0.15 \mathrm{hi}$ \\
\hline 15 & $1.94 \pm 0.30 \mathrm{efg}$ & $0.27 \pm 0.08 \mathrm{j}$ & $2.64 \pm 0.33 \mathrm{~cd}$ & $0.45 \pm 0.24 \mathrm{ij}$ & $1.15 \pm 0.51 \mathrm{~h}$ & $2.42 \pm 0.36 \mathrm{cde}$ & $0.31 \pm 0.36 j$ & $1.41 \pm 0.22 \mathrm{gh}$ \\
\hline Sum & $34.33 \pm 1.54 \mathrm{de}$ & $14.48 \pm 1.11 \mathrm{k}$ & $25.05 \pm 2.29 \mathrm{i}$ & $18.25 \pm 1.55 j$ & $31.04 \pm 1.43 \mathrm{~g}$ & $31.88 \pm 2.00 \mathrm{fg}$ & $17.63 \pm 1.55 j$ & $27.10 \pm 1.48 \mathrm{~h}$ \\
\hline $\begin{array}{l}\text { Polymeric } \\
\text { procyanidins }\end{array}$ & $67.48 \pm 1.99 \mathrm{e}$ & $40.08 \pm 1.64 j$ & $37.37 \pm 1.00 \mathrm{jk}$ & $51.35 \pm 1.70 \mathrm{gh}$ & $62.31 \pm 1.46 \mathrm{f}$ & $90.83 \pm 2.15 c$ & $38.92 \pm 1.02 j$ & $45.83 \pm 0.99 \mathrm{i}$ \\
\hline DP & 4.18 & 2.72 & 3.16 & 3.87 & 3.53 & 3.95 & 2.70 & 2.74 \\
\hline Total & $101.96 \pm 1.14 \mathrm{ef}$ & $55.67 \pm 2.15 n$ & $63.43 \pm 1.11 \mathrm{~m}$ & $70.75 \pm 1.771$ & $95.75 \pm 1.65 \mathrm{~g}$ & $124.95 \pm 1.14 \mathrm{~d}$ & $57.84 \pm 2.05 n$ & $76.79 \pm 1.19 \mathrm{k}$ \\
\hline
\end{tabular}

nd, not detected; \pm standard deviation; DP, degree of polymerization; value in the same columns followed by different letters are significantly different at $p \leq 0.05$ according to Tukey's tes. 


\subsection{Antioxidant and In Vitro Biological Activities}

The interest in compounds with antioxidant properties has been increasing over the last decades, mainly due to the discovery of the role of active oxygen species in chronic non-infectious diseases, such as cardiovascular diseases and cancer. Currently, there are many methods for determining the antioxidant capacity, tailored to the specifics of the test material and taking into account the potential side reactions. Chemical methods for determining the antioxidant capacity are based on the ability to capture synthetic radicals (ABTS), the reduction of metal ions, for example, iron (FRAP), and the measurement of the antioxidant effect on the rate of oxidation processes occurring in the sample (ORAC).

In this study, these three methods were used after measuring the antioxidant capacity of the test samples (Table 4). The analyzed fruits of selected Chaenomeles species and cultivars showed large variation $(p \leq 0.05)$ among the samples. The highest antioxidant capacity, both ABTS and FRAP, was shown by C. $\times$ superba 'Nicoline' (20.61 and $21.32 \mathrm{mmol}$ Trolox/100 $\mathrm{g} \mathrm{dw}$ ) while the lowest was shown by C. speciosa 'Rubra' (10.91 and $10.24 \mathrm{mmol}$ Trolox/100 g dw). The average antioxidant activity measured by ABTS and FRAP methods from the analyzed species was respectively, for $\mathrm{C}$. $\times$ superba (17.39 and $17.18 \mathrm{mmol}$ Trolox/100 $\mathrm{g} \mathrm{dw}$ ), for C. japonica (14.98 and $13.90 \mathrm{mmol}$ Trolox/100 $\mathrm{g} \mathrm{dw}$ ), and for C. speciosa (15.27 and $14.55 \mathrm{mmol}$ Trolox/100 $\mathrm{g} \mathrm{dw}$ ). For comparison, Teleszko and Wojdyło [27] for four Japanese quince cultivars obtained higher values of the activity measured by ABTS and FRAP assays from 44.98 to 68.37 and from 30.73 to $46.57 \mathrm{mmol}$ Trolox/100 $\mathrm{g} \mathrm{dw}$. while Du et al. [2] for C. japonica and C. speciosa, determined similar values for ABTS (36.54 and $14.61 \mathrm{mmol}$ Trolox/100 g dw) and for FRAP (11.39 and $2.80 \mathrm{mmol}$ Trolox/100 $\mathrm{g} \mathrm{dm}$ ), respectively. The strongest antioxidant potential measured by the ORAC test was shown by C. $\times$ superba 'Colour Trail' (66.59 mmol Trolox/100 g dw) and the lowest by C. speciosa 'Rubra' and C. japonica wild \#2 (33.82 and 33.99 mmol Trolox/100 g $\mathrm{dw}$, respectively). The average ORAC activity for the 19 analyzed varieties of Chaenomeles fruits was $48.35 \mathrm{mmol}$ Trolox/100 $\mathrm{g} \mathrm{dw}$ and was higher than for the average ORAC value for the artichoke (27.86 mmol Trolox/100 g dw) [5] or grape seeds (36.46 mmol Trolox/100 g dw) [33]. The Global Report on Diabetes WHO [34] states that diabetes had become a serious chronic disease worldwide, and by 2030 could become the seventh greatest killer in the world. The key issue in the fight against type 2 diabetes is finding effective inhibitors of pancreatic $\alpha$-amylase and intestinal $\alpha$-glucosidase, responsible for reducing the postprandial glycemia. In addition, agents with $\alpha$-glucosidase inhibitory are used as oral hypoglycemic agents. Nevertheless, previous studies $[35,36]$ indicate that Chaenomeles fruits may be a potential inhibitor of $\alpha$-glucosidase. IC50 (mg of dried fruit $/ \mathrm{mL}$ ) for $\alpha$-amylase and $\alpha$-glucosidase ranged from 13.88 (C. $\times$ superba 'Nicoline') to 18.48 (C. speciosa 'Nivalis'), and from 5.08 (C. $\times$ superba 'Texas Scarlet') to 15.19 (C. japonica 'Red Joy'), respectively ( $p \leq 0.05)$. Miao et al. [35] analyzed the $\alpha$-glucosidase inhibition ability of skin from 13 Chaenomeles fruit genotypes in the range 0.05-0.35 $\mathrm{mg} / \mathrm{mL}$ and flesh $0.04-0.43 \mathrm{mg} / \mathrm{mL}$. To compare, the Actinidia fruits of selected cultivars also showed a higher capacity to inhibit $\alpha$-amylase (4.13 to $6.40 \mathrm{mg} / \mathrm{mL}$ ) and $\alpha$-glucosidase (0.18 to $10.00 \mathrm{mg} / \mathrm{mL})$ [6]. 
Table 4. Antioxidant (mmol Trolox/100 g dw), $\alpha$-amylase, $\alpha$-glucosidase, pancreatic lipase, acetylcholinesterase, butyrylcholinesterase (IC 50 , mg/mL),and 15-lipoxygenase inhibitionactivity (\% of inhibition) of various species and cvs. of Chaenomeles fruits.

\begin{tabular}{|c|c|c|c|c|c|c|c|c|c|c|}
\hline \multirow{2}{*}{ Spcecies } & \multirow{2}{*}{ Cultivar } & \multicolumn{3}{|c|}{ Antioxidant Capacity } & \multicolumn{6}{|c|}{ In Vitro Inhibition Activities } \\
\hline & & ABTS & FRAP & ORAC & $\alpha$-amylase & $\alpha$-glucosidase & Pancreatic Lipase & AChE & BuChE & 15-LOX \\
\hline \multirow{11}{*}{$\begin{array}{c}\text { Chaenomeles } \times \\
\text { superba }\end{array}$} & Crimson and Gold & $16.03 \pm 1.04 \mathrm{cdef}$ & $16.00 \pm 0.99 \mathrm{de}$ & $54.93 \pm 1.11 \mathrm{bc}$ & $17.49 \pm 0.88 \mathrm{a}$ & $7.03 \pm 0.20 \mathrm{def}$ & $0.29 \pm 0.01 \mathrm{ab}$ & $11.84 \pm 0.24$ efg & $10.13 \pm 0.97$ efgh & $99.81 \pm 0.15 a$ \\
\hline & Texas Scarlet & $19.63 \pm 0.99 \mathrm{ab}$ & $17.90 \pm 1.22 \mathrm{bcde}$ & $53.89 \pm 1.37 \mathrm{~cd}$ & $14.34 \pm 0.48 \mathrm{~b}$ & $5.08 \pm 0.22 \mathrm{~g}$ & $0.09 \pm 0.00 \mathrm{def}$ & $17.43 \pm 0.56 \mathrm{ab}$ & $8.90 \pm 0.70$ fghi & $43.23 \pm 0.73 \mathrm{f}$ \\
\hline & Nicoline & $20.61 \pm 1.13 \mathrm{a}$ & $21.32 \pm 0.85 a$ & $51.86 \pm 0.90 \mathrm{cde}$ & $13.88 \pm 0.98 \mathrm{~b}$ & $2.67 \pm 0.17 \mathrm{~h}$ & $0.07 \pm 0.02 \mathrm{ef}$ & $16.02 \pm 0.25 \mathrm{bcd}$ & $16.14 \pm 0.79 \mathrm{~d}$ & $71.24 \pm 0.18 \mathrm{~d}$ \\
\hline & Andenken an Karl Ramcke & $18.80 \pm 0.88 \mathrm{abc}$ & $15.51 \pm 1.14 \mathrm{def}$ & $40.38 \pm 0.83 \mathrm{~h}$ & $16.28 \pm 0.77 \mathrm{ab}$ & $6.71 \pm 0.72 \mathrm{defg}$ & $0.04 \pm 0.02 \mathrm{f}$ & $13.03 \pm 0.81$ defg & $9.96 \pm 0.17$ efgh & $74.81 \pm 0.18 \mathrm{c}$ \\
\hline & Pink Lady & $17.65 \pm 1.50$ abcde & $17.29 \pm 0.63 \mathrm{bcde}$ & $57.86 \pm 1.00 \mathrm{~b}$ & $18.01 \pm 0.89 a$ & $5.90 \pm 0.85 \mathrm{fg}$ & $0.20 \pm 0.10 \mathrm{bcd}$ & $15.94 \pm 0.13 \mathrm{bcd}$ & $12.14 \pm 0.87 \mathrm{e}$ & $>100.00$ \\
\hline & Colour Trail & $11.02 \pm 0.72 \mathrm{~h}$ & $10.56 \pm 0.55 \mathrm{~h}$ & $66.59 \pm 0.55 a$ & $17.56 \pm 0.99 a$ & $7.95 \pm 0.16$ cde & $<0.01$ & $17.53 \pm 0.41 \mathrm{ab}$ & $7.85 \pm 0.77 \mathrm{hi}$ & $75.94 \pm 0.29 c$ \\
\hline & Flocon Rose & $15.38 \pm 1.80 \mathrm{defg}$ & $15.32 \pm 0.88 \mathrm{efg}$ & $45.25 \pm 0.99 \mathrm{~g}$ & $15.59 \pm 0.66 \mathrm{ab}$ & $7.18 \pm 0.11 \mathrm{def}$ & $<0.01$ & $11.73 \pm 0.47$ efg & $22.70 \pm 0.63 \mathrm{bc}$ & $98.15 \pm 1.00 \mathrm{a}$ \\
\hline & Hollandia & $18.36 \pm 0.63 \mathrm{abcd}$ & $19.44 \pm 1.11 \mathrm{abc}$ & $40.72 \pm 0.78 \mathrm{~h}$ & $16.49 \pm 0.32 \mathrm{ab}$ & $6.10 \pm 1.23 \mathrm{fg}$ & $<0.01$ & $10.73 \pm 0.74 \mathrm{gh}$ & $15.89 \pm 0.44 \mathrm{~d}$ & $>100.00$ \\
\hline & Jet Trail & $18.91 \pm 0.91 \mathrm{abc}$ & $20.04 \pm 1.37 \mathrm{ab}$ & $54.80 \pm 0.46 \mathrm{bc}$ & $17.97 \pm 1.00 \mathrm{a}$ & $6.97 \pm 0.77 \mathrm{def}$ & $0.29 \pm 0.01 \mathrm{ab}$ & $12.22 \pm 0.65 \mathrm{efg}$ & $8.09 \pm 0.99 \mathrm{ghi}$ & $>100.00$ \\
\hline & wild & $17.46 \pm 0.81 \mathrm{bcde}$ & $18.45 \pm 0.45 \mathrm{abcd}$ & $50.18 \pm 0.89 \mathrm{ef}$ & $18.25 \pm 0.39 \mathrm{a}$ & $7.17 \pm 0.57 \mathrm{def}$ & $<0.01$ & $11.05 \pm 0.57 \mathrm{~g}^{\circ}$ & $31.59 \pm 0.95 a$ & $>100.00$ \\
\hline & Cameo & $15.24 \pm 0.24 \mathrm{efg}$ & $11.93 \pm 0.33 \mathrm{~h}$ & $51.63 \pm 1.62 \mathrm{de}$ & $16.75 \pm 0.57 \mathrm{ab}$ & $8.54 \pm 0.34 \mathrm{~cd}$ & $0.12 \pm 0.02 \mathrm{def}$ & $11.56 \pm 0.84 \mathrm{fg}$ & $12.37 \pm 1.22 \mathrm{e}$ & $36.84 \pm 0.44 \mathrm{~g}$ \\
\hline \multirow{5}{*}{$\begin{array}{l}\text { Chaenomeles } \\
\text { japonica }\end{array}$} & Cido & $18.06 \pm 1.52 \mathrm{abcde}$ & $18.00 \pm 0.65 \mathrm{bcde}$ & $48.48 \pm 1.55 f$ & $16.47 \pm 0.56 \mathrm{ab}$ & $6.49 \pm 0.49 \mathrm{efg}$ & $0.17 \pm 0.00 \mathrm{cde}$ & $14.75 \pm 0.75 \mathrm{bcde}$ & $16.42 \pm 0.31 \mathrm{~d}$ & $42.11 \pm 0.56 \mathrm{f}$ \\
\hline & Red Joy & $13.50 \pm 0.50 \mathrm{fgh}$ & $12.76 \pm 1.12 \mathrm{fgh}$ & $53.43 \pm 0.87 \mathrm{~cd}$ & $17.45 \pm 0.54 a$ & $15.19 \pm 0.14 a$ & $0.06 \pm 0.01 \mathrm{ef}$ & $7.74 \pm 0.34 \mathrm{hi}$ & $6.06 \pm 0.41 \mathrm{i}$ & $73.31 \pm 0.74 \mathrm{~cd}$ \\
\hline & wild \#1 & $12.41 \pm 0.41 \mathrm{gh}$ & $11.53 \pm 0.55 \mathrm{~h}$ & $40.28 \pm 0.66 \mathrm{~h}$ & $16.66 \pm 0.87 \mathrm{ab}$ & $6.11 \pm 0.19$ efg & $0.35 \pm 0.05 a$ & $12.14 \pm 0.20 \mathrm{efg}$ & $32.11 \pm 1.13 a$ & $90.60 \pm 0.69 b$ \\
\hline & wild \#2 & $13.72 \pm 0.72 \mathrm{fgh}$ & $12.30 \pm 0.62 \mathrm{gh}$ & $33.99 \pm 1.74 \mathrm{i}$ & $16.11 \pm 1.13 \mathrm{ab}$ & $9.57 \pm 0.55 \mathrm{c}$ & $<0.01$ & $10.13 \pm 0.30 \mathrm{gh}$ & $20.68 \pm 0.56 \mathrm{c}$ & $70.37 \pm 0.55 \mathrm{~d}$ \\
\hline & n1 (new) & $16.96 \pm 0.96 \mathrm{bcde}$ & $16.90 \pm 0.22 \mathrm{cde}$ & $51.07 \pm 0.77 \mathrm{def}$ & $16.89 \pm 0.98 \mathrm{ab}$ & $6.09 \pm 1.22 \mathrm{fg}$ & $0.25 \pm 0.05 a b c$ & $14.18 \pm 0.49 \mathrm{cdef}$ & $11.17 \pm 0.66 \mathrm{efg}$ & $66.05 \pm 0.99 \mathrm{e}$ \\
\hline \multirow{3}{*}{$\begin{array}{c}\text { Chaenomeles } \\
\text { speciosa }\end{array}$} & Nivalis & $17.54 \pm 0.54 \mathrm{abcde}$ & $16.39 \pm 0.47 \mathrm{cde}$ & $44.30 \pm 1.50 \mathrm{~g}$ & $18.48 \pm 0.43 a$ & $6.56 \pm 0.46 \mathrm{efg}$ & $0.20 \pm 0.02 \mathrm{bcd}$ & $16.52 \pm 35 \mathrm{bc}$ & $11.97 \pm 0.20 \mathrm{ef}$ & $74.81 \pm 0.45 c$ \\
\hline & Rubra & $10.91 \pm 0.91 \mathrm{~h}$ & $10.24 \pm 1.20 \mathrm{~h}$ & $33.82 \pm 0.49 \mathrm{i}$ & $18.38 \pm 0.77 \mathrm{a}$ & $5.74 \pm 0.84 \mathrm{fg}$ & $0.04 \pm 0.00 \mathrm{f}$ & $6.65 \pm 0.73 \mathrm{i}$ & $11.07 \pm 0.81$ efg & $14.29 \pm 0.99 \mathrm{i}$ \\
\hline & Simonii & $17.37 \pm 1.37 \mathrm{bcde}$ & $17.02 \pm 0.98 \mathrm{bcde}$ & $45.18 \pm 1.15 \mathrm{~g}$ & $16.88 \pm 1.00 \mathrm{ab}$ & $12.48 \pm 0.68 \mathrm{~b}$ & $0.20 \pm 0.05 \mathrm{bcd}$ & $20.42 \pm 0.99 \mathrm{a}$ & $25.79 \pm 0.11 \mathrm{~b}$ & $27.37 \pm 0.30 \mathrm{~h}$ \\
\hline
\end{tabular}

\pm standard deviation; value in the same columns followed by different letters are significantly different at $p \leq 0.05$ according to Tukey's test. 
The inhibitory activity of pancreatic lipase is used in the prevention of obesity, because it is responsible for hydrolyzing more than half of the consumed triglycerides, to low-molecular compounds and free fatty acids [37]. Therefore, it reduces the amount of fat absorbed into the blood stream and can be used for weight loss control. Among the Chaenomeles species and cultivars with reference to the inhibitory activity toward pancreatic lipase, significant differences $(p \leq 0.05)$ were observed. The inhibitory effect $\left(\mathrm{IC}_{50}\right)$ of the analyzed fruits ranged from $0.04(C . \times$ superba 'Andenken an Karl Ramcke' and C. speciosa 'Rubra') to $0.35 \mathrm{mg} / \mathrm{mL}$ (C. japonica wild \#1). It should be noted that for five analyzed cultivars, i.e., C. $\times$ superba 'Color Trail', 'Flavon Rose', 'Hollandia', wild, and C. japonica wild \#2, the values of pancreatic lipase inhibition were designated as $<0.01$. This means that a lower concentration of Chaenomeles had the greatest inhibitory potential. The results were similar to those obtained by Nowicka et al. [37] in 20 peach cultivars in the range from 0.07 to $2.06 \mathrm{mg} / \mathrm{mL}$. It should be emphasized that so far there are no data on the activity of Chaenomeles fruit in the literature as regards the inhibition of pancreatic lipase.

Alzheimer's disease is considered as one of the most prevalent neurodegenerative disorders and accounts for more than $80 \%$ of dementia worldwide in the aged population. It is estimated that by 2050 , three new case may develop every minute [38]. Acetylcholinesterase (AChE) and butyrylcholinesterase (BuChE, pseudocholinesterase) are key enzymes in the breakdown of an important neurotransmitter, acetylcholine (ACh). Several clinical trials have confirmed that $\mathrm{ACh}$ inhibitors could be used to treat this pathology [33,38]. $\mathrm{IC}_{50}$ inhibition of $\mathrm{AChE}$ and $\mathrm{BuChE}$ ranged from 6.65 to 20.42 and from 6.06 to $31.59 \mathrm{mg}$ of dried fruit/mL with significant differences between samples $(p \leq 0.05)$. The cultivars showing the highest ability to inhibit AChE and BuChE were found to be C. speciosa 'Rubra' and $C$. japonica 'Red Joy' while the least effective were C. speciosa 'Simonii' and C. Xsuperba wild \#1, respectively. The analyzed Chaenomeles genotypes showed similar mean $\mathrm{AChE}$ and $\mathrm{BuChE}$ inhibition values $\left(\mathrm{IC}_{50}\right)$, 13.24 and $15.32 \mathrm{mg} / \mathrm{mL}$, respectively. It is worth noting that Sancheti et al. [39] during in vivo studies in rats observed a positive effect of the ethyl acetate fraction from Chaenomeles sinensis, which caused a strong decrease in AChE activity in diabetic rats.

Lipoxygenases (LOXs) are important enzymes in lipid metabolism that convert the polyunsaturated fatty acids, arachidonic acid (AA), and linoleic acid (LA), to their corresponding metabolites. The inhibitors of 15-LOX have mainly been of interest in the treatment of inflammatory conditions. Recently, multiple studies have provided evidence to elucidate the relationship of 15-LOX-1 and cancer cell growth and development [40]. The results of 15-LOX inhibition clearly showed the great variation of obtained values between tested genotypes $(p \leq 0.05)$. The 15 -lipoxygenase inhibition activity was expressed as \% inhibition at a sample concentration of $5.77 \mathrm{mg} / \mathrm{mL}$. The highest potential was exhibited by C. $\times$ superba 'Crimson and Gold' and 'Flacon Rose' (99.81\% and $98.15 \%)$, while the lowest was shown by C. speciosa 'Rubra' (14.29\%). C. $\times$ superba 'Pink Lady', 'Hollandia', 'Jet Trail' and wild obtained values out of the range $(>100.00)$, which means that the used Chaenomeles extracts had very strong inhibitory properties against LOX. The obtained results may be a clue to continue research on cell lines and using a simulated digestive system to verify their biological potential. Moreover, it is advisable to carry out in vivo studies, as there is not enough information in this area.

\subsection{Antioxidant On-Line Profiling by HPLC-PDA Coupled with Post-Column Derivatization with ABTS}

Nowadays, sensitive on-line HPLC-ABTS methods for analyzing free radical scavenging activity have been developed. They combine the liquid chromatography system with additional pumps and detectors allowing the individual active components to be characterized with high sensitivity and evaluation of the antioxidant potential of individual compounds from complex mixtures [41]. Figure 1A-C shows the analysis of the three cultivars of Chaenomeles (C. $\times$ superba 'Texas Scarlet', C. $\times$ superba 'Cameo', and C. speciosa 'Nivalis'). The upper chromatogram (positive, black) shows the response after passing through the first detector at a wavelength of $280 \mathrm{~nm}$, and the lower one (negative, blue) is characterized by the response of the eluted compounds after reaction with the radical 
cation ABTS after passing through the second detector $(\lambda=734 \mathrm{~nm})$. The high area of negative peaks on the lower chromatogram is proportional to the activity of individual compounds.

The characteristic elevation of the baseline in the middle part of the upper chromatogram (Figure $1 \mathrm{~A}-\mathrm{C}$ ) is caused by the presence of polymeric procyanidins. A mirror reflection of this elevation in the lower chromatogram indicates that these compounds exhibit significant antioxidant activity. Comparing the intensity of the negative response for (-)-epicatechin (peak 9), which is the second highest peak in the order, it can be clearly seen that its antioxidant activity is disproportionate, because this response is negligible. Comparing the activity of (-)-epicatechin and procyanidin C1 (peak 11), whose signal in the upper chromatogram is almost $50 \%$ lower, they have a very similar response in the lower chromatogram, and hence similar activity. Numerous in vitro and in vivo studies [1] confirm that polyphenol compounds belonging to the flavan-3-ol group have antioxidant and anti-inflammatory properties. Furthermore, the chemical structure of (-)-epicatechin and its polymers makes them better antioxidants than (+)-catechin and its derivatives, but also the type B procyanidins are better antioxidants than the A type procyanidins, and the degree of polymerization (its increase causes an increase in activity) of the compound is important for their pro-health activity [42]. These results are confirmed by Raudone et al. [43], who also observed greater activity of procyanidin oligomers and polymers than (+)-catechin and (-)-epicatechin. The activity of phenolic acids (peaks 4 and 5) is lower than catechins [44], which can be clearly seen in the blue chromatogram. The signal from chlorogenic acid (peak 4) at $280 \mathrm{~nm}$ is significant, whereas its response after reaction with a radical cation is very small. It is caused, among others, by the fact that antioxidant activity increase with the number and position of the $-\mathrm{OH}$ groups on the molecule. To summarize, among all identified polyphenolic compounds, procyanidin B3, B2, C1, and (-)-epicatechin were found to be predominant in building antioxidant capacity of Chaenomeles fruit, in accordance with Zhang et al. [26] and Raudone et al. [43].

\subsection{Agglomerative Hierarchical Clustering (AHC)}

Dendrograms of agglomerative hierarchical clustering (AHC) analysis (Figure 2A,B) showed dissimilarity of biological activities and chemical compounds (A) and between studied cultivars (B) of Chaenomeles fruits obtained by Euclidian distance dissimilarity (within the interval 0 to 65 and 0 to 18 , respectively) using the aggregation criterion, Ward's method.

The horizontal axis of the dendrogram represents the dissimilarity between clusters, while the vertical axis represents the objects. Each leaf corresponds to one object and objects that are similar to each other are combined into branches. The greater the height of the horizontal line, the less similar the objects are. By analyzing Figure 2A, it is visible that two groups are approximately the same size, and the third one has only two states. The first group (displayed in orange color) includes objects showing similarity to the second group (displayed in green color). This confirms the calculated Pearson correlation coefficient $(r)$, which for phenolic acids and inhibition of 15-LOX is equal to 0.23 , and 0.36 for organic acids and inhibition of AChE. In the second group, the branch created between flavan-3-ols and polymeric procyanidins and the activity of ABTS and FRAP is flatter than the others in this cluster. They are more homogeneous with each other (ABTS:flavan-3-ols, $r=0.86$ and ABTS:polymeric procyanidins, $r=0.76$ ). This is further confirmation (apart from on-line ABTS antioxidant profiling) that flavan-3-ols and their polymers are responsible for the antioxidant capacity of Chaenomeles fruits. The third group (displayed in purple) formed between the BuChE and ORAC inhibition activity $(r=0.41)$ is more homogeneous with the remaining two clusters (it is flatter on the dendrogram). This is confirmed by comparing the within-class variable, which is almost $70 \%$ lower. From the analysis of the dendrogram it can be concluded that inhibition of AChE, BuChE and 15-LOX are influenced by the content of phenolic acids and organic acids, while the polyphenol compounds from the flavan-3-ols group, L-ascorbic acid, and sugars formed the activity of Chaenomeles fruit against $\alpha$-amylase and $\alpha$-glucosidase. Considering the relationship between the Chaenomeles genotypes, in the lower dendrogram (Figure 2B), the three clusters can be seen as three branches that occur at about the same horizontal distance. The two outliers, between 'Jet Trail' and 'Crimson and Gold', and 'Red Joy' 
and 'Colour Trail', fused rather arbitrarily at much greater distances. Moreover, two wild genotypes of $C$. japonica are similar in the context of analyzed parameters and form a cluster with $C . \times$ superba wild with dissimilarity less than one. Not with standing, it can be concluded that there is significant variation within the analyzed species, as well as internal cultivars.
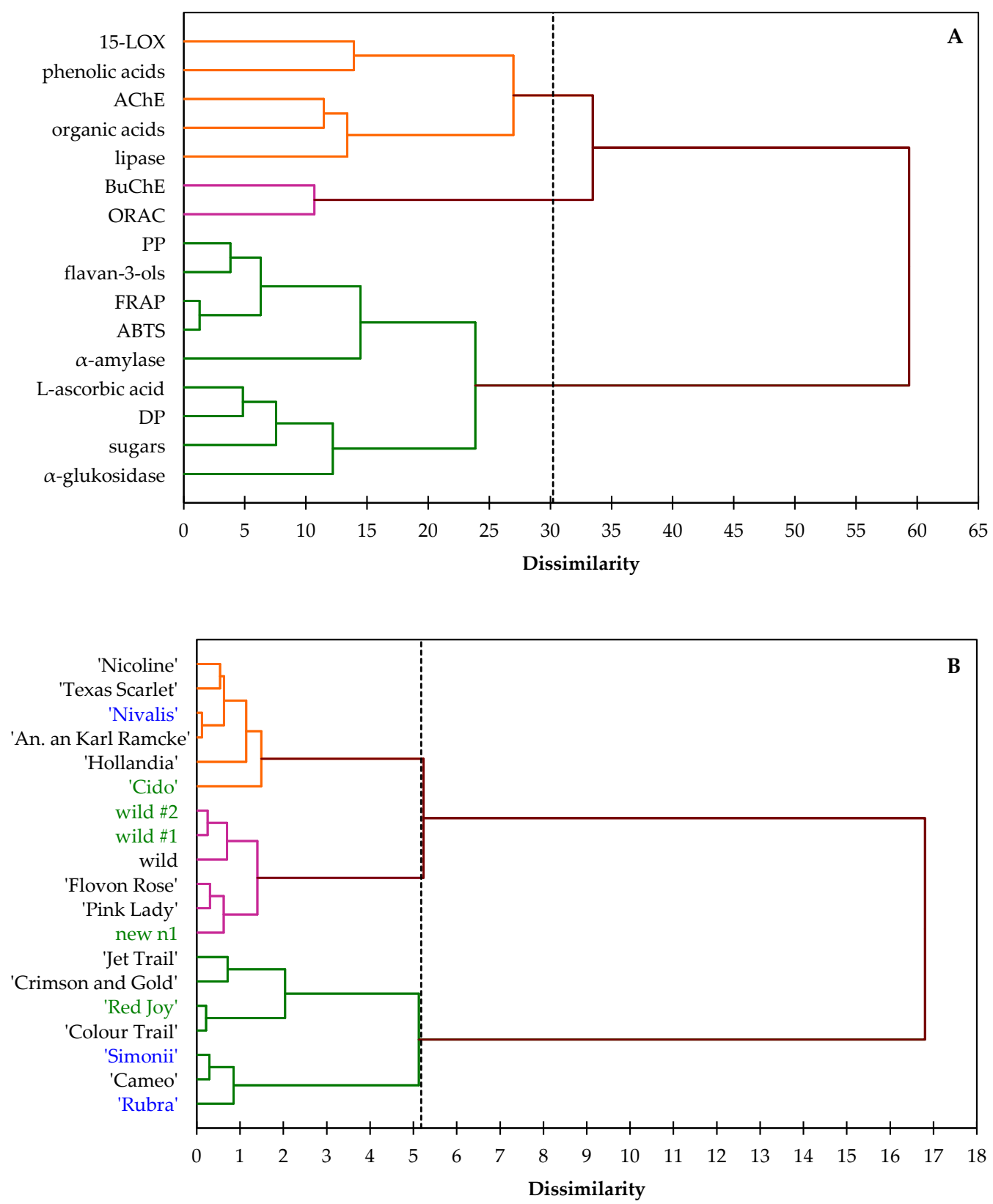

Figure 2. Dendograms of Agglomerative Hierarchical Clustering (AHC) analysis representing dissimilarity relationship of biological activieties and chemical compounds (A) and between studied cultivars (B) of Chaenomeles $\times$ superba (black), C. japonica (green) and C. speciosa (blue). PP - polymeric procyanidins; DP - degree of polimerization.

\section{Conclusions}

Physiochemical composition and biological activities of the nineteen Chaenomeles species and cultivars evaluated in this study revealed a diverse range of polyphenolic compounds and in vitro biological properties (antioxidant, $\alpha$-amylase, $\alpha$-glucosidase, $\mathrm{AChE}, \mathrm{BuChE}$, and 15-LOX inhibition activity). The analyzed fruits are rich in polymeric procyanidins and contain a high level of organic 
acids. Chaenomeles $\times$ superba 'Nicoline' displayed the highest total phenol content $(170.38 \mathrm{~g} / \mathrm{kg} \mathrm{dw})$ while Chaenomeles $\times$ superba 'ColourTrail' was characterized by the highest concentration of polymeric procyanidins $(109.67 \mathrm{~g} / \mathrm{kg} \mathrm{dw})$. Chaenomeles fruits are a good source of malic acid (41.64 to 110.31 $\mathrm{g} / 100 \mathrm{~g} \mathrm{fw}$ ), L-ascorbic acid (30.26 to $1195.05 \mathrm{mg} / 100 \mathrm{~g} \mathrm{fw})$, and pectins ( $0.65 \%$ to1.72\%). In addition, Chaenomeles $\times$ superba 'Nicoline' showed high potential for inhibition $\alpha$-amylase and $\alpha$-glucosidase(as compared with all analyzed species and cultivars), while Chaenomeles japonica 'Red Joy' proved to be an effective inhibitor for AChE and BuChE. The study established Chaenomeles fruits as a source of functional ingredients with possible pharmacological use. However, in order to verify the thesis that Chaenomeles fruits are a source of bioactive compounds showing pro-health properties, it is necessary to use in vivo models in further studies. Gastrointestinal systems should be used to determine the bioavailability and digestibility of the Chaenomeles bioactive compounds. Therefore, the fruits could be important dietary sources of natural antioxidants.

Supplementary Materials: The following are available online at http://www.mdpi.com/2076-3921/9/1/60/s1, Figure S1: Structural formulas of selected phenolic compounds identified in Chaenomeles fruits.

Author Contributions: Conceptualization, I.P.T. and A.W.; methodology, I.P.T., A.W., and K.T.; formal analysis, A.W. and P.N.; investigation, I.P.T. and A.W.; resources, T.G. and P.B.; writing-original draft preparation, I.P.T.; writing-review and editing, I.P.T and A.W.; supervision, A.W.; project administration, I.P.T.; funding acquisition, I.P.T. and A.W. All authors have read and agreed to the published version of the manuscript.

Funding: Work financed from the Ministry of Science and Higher Education budgetary funds for science in 2018-2021, as a research project under the "Diamond Grant" program, DI2017 006347. The publication was the result of the activity of the research group "Plants4food".

Conflicts of Interest: The authors declare no conflict of interest.

\section{References}

1. Nahorska, A.; Dzwoniarska, M.; Thiem, B. Owoce pigwowca japońskiego (Chaenomeles japonica (Thunb.) Lindl. ex Spach) źródłem substancji biologicznie aktywnych. Postępy Fitoterapii 2014, 4, 239-246.

2. Du, H.; Wu, J.; Li, H.; Zhong, P.-X.; Xu, Y.-J.; Li, C.-H.; Ji, K.-X.; Wang, L. Polyphenols and triterpenes from Chaenomeles fruits: Chemical analysis and antioxidant activities assessment. Food Chem. 2013, 141, 4260-4268. [CrossRef]

3. Zhang, S.Y.; Han, L.Y.; Zhang, H.; Xin, H.L. Chaenomeles speciosa: A review of chemistry and pharmacology. Biomed. Rep. 2014, 2, 12-18. [CrossRef] [PubMed]

4. Gorlach, S.; Wagner, W.; Podsędek, A.; Szewczyk, K.; Koziołkiewicz, M.; Dastych, J. Procyanidins from Japanese quince (Chaenomeles japonica) fruit induce apoptosis in human colon cancer Caco-2 cells in a degree of polymerization-dependent manner. Nutr. Cancer 2011, 63, 1348-1360. [CrossRef] [PubMed]

5. Turkiewicz, I.P.; Wojdyło, A.; Tkacz, K.; Nowicka, P.; Hernández, F. Antidiabetic, anticholinesterase and antioxidant activity vs. terpenoids and phenolic compounds in selected new cultivars and hybrids of artichoke Cynara scolymus L. Molecules 2019, 24, 1222. [CrossRef] [PubMed]

6. Wojdyło, A.; Nowicka, P.; Oszmiański, J.; Golis, T. Phytochemical compounds and biological effects of Actinidia fruits. J. Funct. Foods 2017, 30, 194-202. [CrossRef]

7. Pijanowski, E.; Mrożewski, S.; Horubała, A.; Jarczyk, A. Technologia Produktów Owocowych i Warzywnych; Państwowe Wydawnictwa Rolnicze iLeśne: Warsaw, Poland, 1973; Volume 1, p. 634.

8. Wojdyło, A.; Oszmiański, J.; Bielicki, P. Comparison of polyphenolic composition, antioxidant activity and PPO activity of some cultivars of quince (Cydonia oblonga Miller) fruits. J. Agric. Food Chem. 2013, 61, 2762-2772. [CrossRef]

9. Re, R.; Pellegrini, N.; Proteggente, A.; Pannala, A.; Yang, M.; Rice-Evans, C. Antioxidant activity applying an improved ABTS radical cation decolorization assay. Free Radic. Biol. Med. 1999, 26, 1231-1237. [CrossRef]

10. Benzie, I.F.F.; Strain, J.J. The ferric reducing ability of plasma (FRAP) as a measure of "Antioxidant Power": The FRAP assay. Anal. Biochem. 1996, 239, 70-76. [CrossRef]

11. Ou, B.; Hampsch-Woodill, M.; Prior, R.L. Development and Validation of an Improved Oxygen Radical Absorbance Capacity Assay Using Fluorescein as the Fluorescent Probe. J. Agric. Food Chem. 2001, 49, 4619-4626. [CrossRef] 
12. Wojdyło, A.; Nowicka, P.; Babelewski, P. Phenolic and carotenoid profile of new goji cultivars and their anti-hyperglycemic, anti-aging and antioxidant properties. J. Funct. Foods 2018, 48, 632-642. [CrossRef]

13. Chung, L.Y.; Soo, W.K.; Chan, K.Y.; Mustafa, M.R.; Goh, S.H.; Imiyabir, Z. Lipoxygenase inhibiting activity of some Malaysian plants. Pharm. Biol. 2009, 47, 1142-1148. [CrossRef]

14. Turkiewicz, I.P.; Wojdyło, A.; Lech, K.; Tkacz, K.; Nowicka, P. Influence of different drying methods on the quality of Japanese quince fruit. LWT 2019, 114, 108416. [CrossRef]

15. Thomas, M.; Guillemin, F.; Guillon, F.; Thibault, J.-F. Pectins in the fruits of Japanese quince (Chaenomeles japonica). Carbohydr. Polym. 2003, 53, 361-372. [CrossRef]

16. Tarko, T.; Duda-Chodak, A.; Satora, P.; Sroka, P.; Pogoń, P.; Machalica, J. Chaenomeles japonica, Cornus mas, Morus nigra fruits characteristics and their processing potential. J. Food Sci. Technol. 2014, 51, 3934-3941. [CrossRef]

17. Lesińska, E. Charakterystyka skladu chemicznego owocow pigwowca i ocena ich technologicznej przydatnosci dla przetworstwa owocowo-warzywnego. In Zeszyty Naukowe Akademi Rolniczej im. H. Kołłataja w Krakowie. Rozprawa Habilitacyjna; Wydawnictwo Akademii Rolniczej im. H. Kołłąaja: Kraków, Poland, 1986; p. 118.

18. Rubinskienė, M.; Viškelis, P.; Viškelis, J.; Bobinaitė, R.; Shalkevich, M.; Pigul, M.; Urbonavičienè, D. Biochemical composition and antioxidant activity of Japanese quince (Chaenomeles japonica) fruit, their syrup and candied fruit slices. Sodininkystè ir Daržininkystè 2014, 33, 45-52.

19. Ros, J.; Laencina, J.; Hellın, P.; Jordan, M.; Vila, R.; Rumpunen, K. Characterization of juice in fruits of different Chaenomeles species. LWT Food Sci. Technol. 2004, 37, 301-307. [CrossRef]

20. Bieniasz, M.; Dziedzic, E.; Kaczmarczyk, E. The effect of storage and processing on vitamin C content in Japanese quince fruit. Folia Hortic. 2017, 29, 83-93. [CrossRef]

21. Lee, S.K.; Kader, A.A. Preharvest and postharvest factors influencing vitamin $C$ content of horticultural crops. Postharvest Biol. Technol. 2000, 20, 207-220. [CrossRef]

22. Hellín, P.; Vila, R.; Jordán, M.J.; Laencina Sánchez, J.; Rumpunen, K.; Ros-García, J.M. Characteristics and composition of Chaenomeles fruit juice. In Japanese Quince-Potential Fruit Crop for Northern Europe; Rumpunen, K., Ed.; Swedish University of Agricultural Sciences: Alnarp, Sweden, 2003; pp. 127-140.

23. Lesińska, E. Characteristics of sugars and acids in the fruits of East Asian quince. Die Nahr. 1987, 31, 763-765. [CrossRef]

24. Lesińska, E.; Przybylski, R.; Eskin, M. Some Volatile and nonvolatile flavor components of the dwarf quince (Chaenomeles japonica). J. Food Sci. 1988, 53, 854-856. [CrossRef]

25. Owczarek, K.; Hrabec, E.; Fichna, J.; Sosnowska, D.; Koziołkiewicz, M.; Szymański, J.; Lewandowska, U. Flavanols from Japanese quince (Chaenomeles japonica) fruit suppress expression of cyclooxygenase-2, metalloproteinase-9, and nuclear factor-kappaB in human colon cancer cells. Acta Biochim. Pol. 2017, 64, 567-576. [CrossRef] [PubMed]

26. Zhang, M.; Zhao, R.; Zhou, S.; Liu, W.; Liang, Y.; Zhao, Z.; Li, S.; Wang, X.; Wong, T.; Zhao, H. Chemical characterization and evaluation of the antioxidants in Chaenomeles fruits by an improved HPLC-TOF/MS coupled to an on-line DPPH-HPLC method. J. Environ. Sci. Health Part C 2018, 36, 43-62. [CrossRef] [PubMed]

27. Teleszko, M.; Wojdyło, A. Comparison of phenolic compounds and antioxidant potential between selected edible fruits and their leaves. J. Funct. Foods 2015, 14, 736-746. [CrossRef]

28. Sun, J.; Liang, F.; Bin, Y.; Li, P.; Duan, C. Screening non-colored phenolics in red wines using liquid chromatography/ultraviolet and mass spectrometry/mass spectrometry libraries. Molecules 2007, 12, 679-693. [CrossRef] [PubMed]

29. Bravo, M.; Silva, S.; Coelho, A.; Boas, L.V.; Bronze, M. Analysis of phenolic compounds in Muscatel wines produced in Portugal. Anal. Chim. Acta 2006, 563, 84-92. [CrossRef]

30. Stöggl, W.; Huck, C.; Bonn, G.K. Structural elucidation of catechin and epicatechin in sorrel leaf extracts using liquid-chromatography coupled to diode array-, fluorescence-, and mass spectrometric detection. J.Sep. Sci. 2004, 27, 524-528. [CrossRef]

31. Lewandowska, U.; Szewczyk, K.; Owczarek, K.; Hrabec, Z.; Podsędek, A.; Koziołkiewicz, M.; Hrabec, E. Flavanols from Japanese quince (Chaenomeles japonica) fruit inhibit human prostate and breast cancer cell line invasiveness and cause favorable changes in Bax/Bcl-2 mRNA ratio. Nutr. Cancer 2013, 65, 273-285. [CrossRef] 
32. Wojdyło, A.; Figiel, A.; Lech, K.; Nowicka, P.; Oszmiański, J. Effect of convective and vacuum-microwave drying on the bioactive compounds, color, and antioxidant capacity of sour cherries. Food Bioprocess Technol. 2014, 7, 829-841. [CrossRef]

33. Tkacz, K.; Wojdyło, A.; Nowicka, P.; Turkiewicz, I.; Golis, T. Characterization in vitro potency of biological active fractions of seeds, skins and flesh from selected Vitis vinifera L. cultivars and interspecific hybrids. J. Funct. Foods 2019, 56, 353-363. [CrossRef]

34. World Health Organization (WHO). Global Report on Diabetes. 2016. Available online: https://www.who.int/ diabetes/global-report/en/ (accessed on 10 October 2019).

35. Miao, J.; Li, X.; Zhao, C.; Gao, X.; Wang, Y.; Cheng, K.; Gao, W. Solvents effect on active chemicals and activities of antioxidant, anti- $\alpha$-glucosidase and inhibit effect on smooth muscle contraction of isolated rat jejunum of Chaenomeles speciosa. J. Funct. Foods 2018, 40, 146-155. [CrossRef]

36. Miao, J.; Zhao, C.; Li, X.; Chen, X.; Mao, X.; Huang, H.; Wang, T.; Gao, W. Chemical composition and bioactivities of two common Chaenomeles fruits in China: Chaenomeles speciosa and Chaenomeles sinensis. J. Food Sci. 2016, 81, H2049-H2058. [CrossRef]

37. Nowicka, P.; Wojdyło, A.; Laskowski, P. Inhibitory potential against digestive enzymes linked to obesity and type 2 diabetes and content of bioactive compounds in 20 cultivars of the peach fruit grown in Poland. Plant Foods Hum. Nutr. 2018, 73, 314-320. [CrossRef] [PubMed]

38. Honarvar, N.M.; Saedisomeolia, A.; Abdolahi, M.; Shayeganrad, A.; Sangsari, G.T.; Rad, B.H.; Muench, G. Molecular anti-inflammatory mechanisms of retinoids and carotenoids in Alzheimer's disease: A review of current evidence. J. Mol. Neurosci. 2017, 61, 289-304. [CrossRef] [PubMed]

39. Sancheti, S.; Sancheti, S.; Seo, S.-Y. Antidiabetic and antiacetylcholinesterase effects of ethyl acetate fraction of Chaenomeles sinensis (Thouin) Koehne fruits in streptozotocin-induced diabetic rats. Exp. Toxicol. Pathol. 2013, 65, 55-60. [CrossRef] [PubMed]

40. Orafaie, A.; Matin, M.M.; Sadeghian, H. The importance of 15-lipoxygenase inhibitors in cancer treatment. Cancer Metastasis Rev. 2018, 37, 397-408. [CrossRef]

41. Burnaz, N.A.; Küçük, M.; Akar, Z. An on-line HPLC system for detection of antioxidant compounds in some plant extracts by comparing three different methods. J. Chromatogr. B 2017, 1052, 66-72. [CrossRef]

42. Wood, J.E.; Senthilmohan, S.T.; Peskin, A.V. Antioxidant activity of procyanidin-containing plant extracts at different pHs. Food Chem. 2002, 77, 155-161. [CrossRef]

43. Raudone, L.; Raudonis, R.; Liaudanskas, M.; Viskelis, J.; Pukalskas, A.; Janulis, V. Phenolic profiles and contribution of individual compounds to antioxidant activity of apple powders. J. Food Sci. 2016, 81, C1055-C1061. [CrossRef]

44. Çelik, S.E.; Özyürek, M.; Güçlü, K.; Apak, R. Solvent effects on the antioxidant capacity of lipophilic and hydrophilic antioxidants measured by CUPRAC, ABTS/persulphate and FRAP methods. Talanta 2010, 81, 1300-1309. [CrossRef]

(C) 2020 by the authors. Licensee MDPI, Basel, Switzerland. This article is an open access article distributed under the terms and conditions of the Creative Commons Attribution (CC BY) license (http://creativecommons.org/licenses/by/4.0/). 